\title{
Fe-Ni-bearing serpentines from the saprolite horizon of Caribbean Ni-laterite deposits: new insights from thermodynamic calculations
}

Cristina

AQ1

Villanova-de-Benavent, ${ }^{1, *}$

Phone + 34934021341

Emailcvillanovadb@ub.edu

Cristina Domènech, 1

Esperança Tauler, ${ }^{1}$

Salvador Galí, 1

Santiago Tassara, 2

Joaquín A. Proenza, 1

1 Departament de Cristal-lografia, Mineralogia i Dipòsits Minerals, Facultat de Geologia

AQ2

, Universitat de Barcelona (UB), C/ Martí i Franquès, s/n -08028, Barcelona, Spain

2 Departamento de Geología, Facultad de Ciencias Físicas y

Matemáticas, Universidad de Chile, Plaza Ercilla 803, Santiago, Chile

\section{Abstract}

$\mathrm{Fe}-\mathrm{Ni}$-bearing serpentine from the saprolite horizon is the main $\mathrm{Ni}$ ores in hydrous silicate-type $\mathrm{Ni}$ laterites and formed by chemical weathering of partially serpentinized ultramafic rocks under tropical conditions. During lateritization, $\mathrm{Mg}, \mathrm{Si}$, and $\mathrm{Ni}$ are leached from the surface and transported downwards. $\mathrm{Fe}^{2+}$ is oxidized to $\mathrm{Fe}^{3+}$ and fixed as insoluble 
Fe-oxyhydroxides (mostly goethite) that incorporate $\mathrm{Ni}$. This $\mathrm{Ni}$ is later leached from goethite and incorporated in secondary serpentine and garnierite. As a result, a serpentine-dominated saprolite horizon forms over the ultramafic protolith, overlapped by a Fe-oxyhydroxide-dominated limonite horizon. The serpentine from the protolith (serpentine I) is of hydrothermal origin and yields similar $\mathrm{Ni}(0.10-0.62 \mathrm{wt} . \% \mathrm{NiO})$ and lower $\mathrm{Fe}$ (mostly $1.37-5.81 \mathrm{wt} . \% \mathrm{FeO}$ ) concentrations than the primary olivine. In contrast, $\mathrm{Fe}-\mathrm{Ni}$-bearing serpentine from the saprolite (serpentine II) shows significantly higher and variable $\mathrm{Fe}$ and $\mathrm{Ni}$ contents, typically ranging from 2.23 to 15.59 wt. $\% \mathrm{Fe}_{2} \mathrm{O}_{3}$ and from 1.30 to $7.67 \mathrm{wt}$ \% $\mathrm{NiO}$, suggesting that serpentine get enriched in $\mathrm{Fe}$ and $\mathrm{Ni}$ under supergene conditions. This study presents detailed mineralogical, textural, and chemical data on this serpentine II, as well as new insights by thermodynamic calculations assuming ideal solution between $\mathrm{Fe}$-, $\mathrm{Ni}$ - and $\mathrm{Mg}$-pure serpentines. The aim is to assess if at atmospheric pressure and temperature Fe-Ni-bearing serpentine can be formed by precipitation. Results indicate that the formation of serpentine II under atmospheric pressure and temperature is thermodynamically supported, and $\mathrm{pH}$, Eh, and the equilibrium constant of the reaction are the parameters that affect the results more significantly.

\section{Keywords}

$\mathrm{Fe}-\mathrm{Ni}$-serpentine

Saprolite

Ni-laterite deposits

Caribbean

Thermodynamics

\section{Introduction}

\section{AQ3}

$\mathrm{Fe}-\mathrm{Ni}$-serpentine represents one of the main sources of Ni in many Ni-laterite deposits worldwide (Freyssinet et al. 2005). Ni-laterite deposits account for about $40 \%$ of the world's annual production of $\mathrm{Ni}$, they host over $60 \%$ of the world land-based Ni resources (Gleeson et al. 2003; Kuck 2013) and the amount of Ni being mined from laterite ores is increasing steadily (Mudd 2010).

Ni-laterite deposits result from the tropical weathering of ultramafic rocks, 
typically serpentinized peridotite (harzburgite, lherzolite, and dunite), and $\sim 67 \%$ forming part of ophiolite complexes (Mudd and Jowitt, 2014;

Golightly, personal communication). Ni-laterites are classified into three groups, according to the main Ni-bearing assemblages: (a) oxide type, dominated by Fe-oxyhydroxides, (b) clay silicate type, in which $\mathrm{Ni}$ is concentrated in smectite group minerals, and (c) hydrous silicate type, where ore minerals are mainly $\mathrm{Mg}-\mathrm{Ni}$ phyllosilicates, including $\mathrm{Fe}-\mathrm{Ni}$-serpentine and garnierite, the latter being the one with highest grades $(1.8-2.5 \mathrm{wt} . \% \mathrm{Ni})$ (Brand et al. 1998; Freyssinet et al. 2005).

Hydrous Mg silicate Ni-laterite deposits are characterized by a thick serpentine-dominated saprolite horizon covered by a Fe-oxyhydroxidedominated limonite horizon.

The combination of tropical climate with intense rainfall, low water table and continuous tectonic uplift produces physical and chemical weathering that leads to the dissolution of the primary ferromagnesian minerals of the ultramafic protolith and the formation of Fe-oxyhydroxides (Roqué-Rosell et al. 2010) and secondary Ni-bearing Mg phyllosilicates (Villanovade-Benavent et al. 2014; Cathelineau et al. 2015).

AQ4

Alteration begins in crystal joints and cracks in peridotite that provides access for water (Pelletier 1996). Among peridotite forming minerals, olivine is considered the most unstable mineral and the first to weather following the hydrolysis reaction 1 (modified from Freyssinet et al. 2005):

$$
\left(\mathrm{Fe}_{x} \mathrm{Mg}_{1-x}\right)_{2} \mathrm{SiO}_{4}+4 x \mathrm{H}_{2} \mathrm{O}=\mathrm{H}_{4} \mathrm{SiO}_{4}+2 x \mathrm{FeOOH}+(2-2 x) \mathrm{Mg}^{2+}+2 x \mathrm{e}^{-}+
$$

$\mathrm{Mg}$ is ultimately leached out of the profile, whereas $\mathrm{Fe}^{2+}$ is oxidized to $\mathrm{Fe}^{3+}$ and subsequently concentrated as Fe-oxyhydroxides (mainly goethite) in the limonite horizon (Golightly 2010).

As olivine represents also the main Ni-bearing mineral in the protolith, $\mathrm{Ni}$ gets released during weathering but is retained in the profile by absorption onto goethite. As weathering continues, goethite may be eventually dissolved and reprecipitated, leaching some Ni following reaction 2 (Freyssinet et al. 2005 ):

$\mathrm{FeOOH}(\mathrm{Ni})(\mathrm{OH})_{2}+2 \mathrm{H}^{+}=\mathrm{FeOOH}+\mathrm{Ni}^{2+}+2 \mathrm{H}_{2} \mathrm{O}$ 
Ni released by goethite can be incorporated in primary (hydrothermal) serpentine (hereafter serpentine I) from the protolith, formed prior to weathering and lateritization of the peridotite body, thus leading to the formation of a secondary $\mathrm{Fe}-\mathrm{Ni}$-enriched serpentine (serpentine II) following reaction 3 (Freyssinet et al. 2005) or the precipitation of garnierites in open fractures (Pelletier 1996).

$$
\mathrm{Mg}_{3} \mathrm{Si}_{2} \mathrm{O}_{5}(\mathrm{OH})_{4}+3 \mathrm{Ni}^{2+}=\mathrm{Ni}_{3} \mathrm{Si}_{2} \mathrm{O}_{5}(\mathrm{OH})_{4}+3 \mathrm{Mg}^{2+}
$$

Serpentine II is the main constituent of the saprolite horizon and the main $\mathrm{Ni}$ ore mineral in volume in hydrous silicate-type Ni-laterite profiles. Serpentine II has already been described by others; however, different names have been used: "weathered serpentines" (Golightly and Arancibia 1979; Golightly 1981 ), "primary weathered serpentine" (Pelletier 1996), "nickeloan serpentine" (Brand et al. 1998), and "altered primary serpentine" (Freyssinet et al. 2005).

Whereas recent studies have focused on Ni-rich garnierite mineralization (Tauler et al. 2009; Wells et al. 2009; Villanova-de-Benavent et al. 2014; Cathelineau et al. 2015), only three studies investigated compositional variations of these serpentines II of the saprolite horizon in detail (Golightly and Arancibia 1979; Pelletier 1996; Chen et al. 2004).

Golightly and Arancibia (1979) studied several samples of unweathered and weathered serpentines from Indonesia, where $6 \%$ of the world's Ni reserves are located (Kuck 2015). They observed, in the Ni-laterite profile of Soroako, that weathered serpentine (serpentine II in this contribution) had a low $\mathrm{Mg}$ content and increased $\mathrm{Fe}\left(4-8\right.$ wt. $\% \mathrm{Fe}_{2} \mathrm{O}_{3}$ ) and $\mathrm{Ni}(1-8$ wt. \% NiO) contents relative to the unweathered serpentine (here serpentine I). Pelletier (1996) performed a study on hydrous silicate Ni-laterite deposits of New Caledonia, which represent $15 \%$ of the world's Ni reserves (Kuck 2015). Pelletier (1996) observed that secondary nickeliferous serpentine (serpentine II), associated with garnierite and resulting from weathering of serpentine I, was enriched in $\mathrm{Ni}(1-7 \mathrm{wt} . \% \mathrm{NiO})$ and also in $\mathrm{Fe}\left(7-17\right.$ wt.\% $\left.\mathrm{Fe}_{2} \mathrm{O}_{3}\right)$. 
The Caribbean region hosts $10 \%$ of the world's Ni resources, mostly in the northern part, which includes the Moa Bay and Punta Gorda deposits in eastern Cuba and the Falcondo deposit in central Dominican Republic (Dalvi et al. 2004; Lewis et al. 2006; Nelson et al. 2011; Aiglsperger et al. 2016). Preliminary mineralogical, textural and chemical studies on serpentine from the saprolite horizon of Caribbean Ni-laterites revealed two different serpentine generations (Tauler et al. 2007; Proenza et al. 2007; Gallardo et al. 2010). Serpentine I, which surrounds olivine grains in a mesh texture arrangement, has low $\mathrm{Ni}$ and $\mathrm{Fe}$ contents, comparable with those of the primary olivine (mostly less than $0.5 \mathrm{wt} . \% \mathrm{NiO}$ ). In contrast, the serpentine II that replaced serpentine $\mathrm{I}$ is enriched in $\mathrm{Ni}$ (up to $3 \mathrm{wt} . \% \mathrm{NiO}$ ) with respect to serpentine I. In addition, serpentine II yielded higher Fe contents than serpentine I (Tauler et al. 2007).

The replacement of $\mathrm{Mg}^{2+}$ by $\mathrm{Ni}^{2+}$ or $\mathrm{Fe}^{3+}$ in serpentine would stabilize the silica excess in serpentine caused by the incongruent dissolution of serpentine that enhances the leaching of $\mathrm{Mg}^{2+}$ (Golightly 1981). Freyssinet et al. (2005) suggested that $\mathrm{Ni}$ exchanges for $\mathrm{Mg}$ in octahedral sites of serpentine II without solution, recrystallisation, or neoformation.

Given the economic importance of $\mathrm{Ni}$, these studies mostly focus on the incorporation of this element in serpentine in the lateritic environment. In contrast, the presence of Fe in serpentine has recently been studied as a key factor during serpentinization (Klein et al. 2009) but has not been studied in lateritic environments. In addition to these authors, Streit et al. (2012) reported that serpentine may contain significant amounts of $\mathrm{Fe}^{3+}$. The incorporation of ferric iron in serpentine takes place in the form of a ferriTschermak substitution, where $\mathrm{Fe}^{3+}$ substitutes for $\mathrm{Mg}$ (in octahedral sites) and for $\mathrm{Si}$ (in tetrahedral sites) to form the cronstedtite component of serpentine $\left.\left(\mathrm{Fe}^{2+}{ }_{2} \mathrm{Fe}^{3+}\right)\left(\mathrm{SiFe}^{3+}\right) \mathrm{O}_{5}(\mathrm{OH})_{4}\right)$. It also may substitute in the octahedral site, that would be charge balanced by some vacancies, forming a ferrian serpentine with the formula $\left(\square \mathrm{Fe}_{2}^{3+}{ }_{2}\right) \mathrm{Si}_{2} \mathrm{O}_{5}(\mathrm{OH})_{4}$, the Fe-analog of kaolinite (Wicks and Plant 1979; Evans 2008; Evans et al. 2009).

AQ6

AQ7

Whereas Golightly and Arancibia (1979) and Golightly (1981) suggested that $\mathrm{Fe}^{3+}$ in serpentine comes from the dissolution of magnetite according to reaction 4 (modified from Golightly 1981), the incorporation of $\mathrm{Fe}^{3+}$ in the 
serpentine structure is not well constrained under weathering conditions.

$3 \mathrm{Mg}_{3} S i_{2} \mathrm{O}_{5}(\mathrm{OH})_{4}+18 \mathrm{H}^{+}+\frac{1}{2} \mathrm{O}_{2}+2 \mathrm{Fe}_{3} \mathrm{O}_{4}=3 \mathrm{Fe}_{2} \mathrm{Si}_{2} \mathrm{O}_{5}(\mathrm{OH})_{4}+9 \mathrm{Mg}^{2+}+9$

Thermodynamic modeling may give further insight into the $\mathrm{Fe}^{3+}$ enrichment in a Ni-laterite environment. Therefore, the aim of the present study is to shed light on the process of $\mathrm{Fe}$ and $\mathrm{Ni}$ enrichment in $\mathrm{Fe}-\mathrm{Ni}$-serpentine of $\mathrm{Ni}$-laterite deposits by combining the knowledge on compositional variations of serpentine II and detailed mineralogical analyses, with thermodynamic and geochemical calculations concerning serpentine II stability. This is used to discuss if serpentine II might form under atmospheric pressure and temperature conditions through dissolution/precipitation processes.

\section{Geological setting}

This study considers two hydrous Mg silicate Ni-laterite deposits located in the Caribbean region: Yamanigüey (Eastern Cuba) and Falcondo (Central Dominican Republic). The Ni-laterite deposits in the Caribbean region developed from ophiolite-related peridotites, which were emplaced during the Cretaceous, with lateritization and subsequent ore deposit formation commencing in the Miocene (Lewis et al. 2006). The Yamaniguiey Ni-laterite deposit, located in Moa Bay mining area, eastern Cuba, developed on serpentinized harzburgite and dunite from the Mayarí-Baracoa ophiolite belt (Proenza et al. 1999; Marchesi et al. 2006). The ultramafic protolith consists of olivine $\left(\mathrm{Fo}_{86-92}\right)$ with $0.16-0.39$ wt.\% $\mathrm{NiO}$, orthopyroxene $\left(\mathrm{En}_{69-89}\right.$ with $\mathrm{NiO}$ below 0.1 wt. \%), and clinopyroxene ( $\mathrm{Mg}$ from 78 to $92, \mathrm{Wo}_{43-48}, \mathrm{Al}_{2} \mathrm{O}_{3}$ from 2.2-4.2 wt.\%; Proenza et al. 2007). The thickness of the profile in Yamaniguiey is about $12 \mathrm{~m}$. The main mineral phases in the saprolite horizon are serpentines I and II, with minor magnetite and goethite (Proenza et al. 2007 ). According to Normando (2006), the Ni grade in the saprolite horizon can reach values of $1.76 \mathrm{wt} . \% \mathrm{Ni}$.

AQ8

The Falcondo Ni-laterite mining area comprises different ore deposits, and samples were taken from the Loma Ortega and Loma Caribe deposits. These deposits developed on the serpentinized Loma Caribe peridotite belt, which was interpreted by Lewis and Jiménez (1991) as a serpentinized harzburgite from an ophiolite complex. The major constituent of the host ultramafic rocks is olivine $\left(\mathrm{Fo}_{80-92}\right)$ with $\mathrm{NiO}$ contents between 0.35 and $0.55 \mathrm{wt} . \%$, followed 
by orthopyroxene $\left(\mathrm{En}_{89-92}\right)$ with $\mathrm{NiO}$ below $0.1 \mathrm{wt} . \%$, and minor clinopyroxene (Haldemann et al. 1979; Lewis et al. 2006; Lithgow 1993; Marchesi et al. 2012). The thickness of the Falcondo Ni-laterite profile varies from 1 to $60 \mathrm{~m}$ (Haldemann et al. 1979). The major Ni-bearing mineral phases are located in the lower saprolite horizon, and comprise serpentine II and garnierites (Tauler et al. 2009; Villanova-de-Benavent et al. 2014). The Falcondo Ni-laterite deposit has 67.8 Mt. indicated Ni resources at an average grade of 1.5 wt.\% Ni (Aiglsperger et al. 2016).

\section{Materials and methods}

For this study, one sample from the saprolite horizon of the Ni-laterite deposit of Yamaniguiey, two of Loma Caribe and one of Loma Ortega were selected. These four samples were characterized mineralogical and chemically by means of powder X-ray diffraction (XRD), optical and scanning electron microscopy (SEM-EDS), and electron microanalysis (EPMA) in the Centers Científics i Tecnològics of the Universitat de Barcelona (CCiT-UB). The data were used to perform geochemical calculations in order to determine the stability field of serpentine II and to study whether this $\mathrm{Ni}$ and Fe enrichment can take place in supergene conditions.

The samples were powdered with an agate mortar and pestle. The instrument used is a PANalytical X'Pert PRO MPD Alpha1 powder diffractometer in Bragg-Brentano $\theta / 2 \theta$ geometry, using $\mathrm{Cu}$ k $\alpha 1$ radiation $(\lambda=1.5406 \AA)$ and working power of $45 \mathrm{kV}-40 \mathrm{~mA}$. Polished thin sections were examined under optical microscopy and using a Scanning Electron Microscope (SEM) Quanta 200 FEI, XTE 325/D8395, equipped with an INCA Energy dispersive spectrometer 250 microanalysis system (EDS), with the operating conditions of $20 \mathrm{kV}$ and $5 \mathrm{nA}$. Mineral chemistry was determined by electron microanalysis (EPMA). The Cameca SX-50 EPMA is equipped with four wavelength dispersive spectrometers (WDS) and an energy dispersive spectrometer (EDS), and operated at $20 \mathrm{kV}, 15 \mathrm{nA}, 2 \mu \mathrm{m}$ beam diameter, and counting time of $20 \mathrm{~s} /$ element. The JEOL JXA-8230 EPMA is equipped with five WDS and an EDS. The operation conditions were $20 \mathrm{kV}, 10 \mathrm{nA}, 2 \mu \mathrm{m}$ beam diameter, and counting time of 20 s/element. The calibration standards used were: hematite (Fe, LIF, K $\alpha$ ), rutile (Ti, PET, K $\alpha$ ), periclase $(\mathrm{Mg}$, TAP, $\mathrm{K} \alpha$ ), rhodonite (Mn, LIF, $\mathrm{K} \alpha$ ), $\mathrm{Al}_{2} \mathrm{O}_{3}(\mathrm{Al}, \mathrm{TAP}, \mathrm{K} \alpha), \mathrm{Cr}_{2} \mathrm{O}_{3}(\mathrm{Cr}, \mathrm{PET}, \mathrm{K} \alpha$ ),

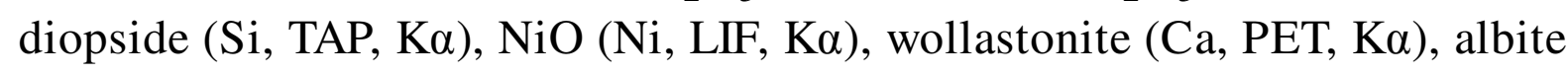
(Na, TAP, K $\alpha$ ), orthoclase (K, TAP, K $\alpha$ ), and metallic cobalt (Co, LIF, K $\alpha$ ). 
The structural formulae of serpentine were calculated on the basis of seven oxygens. In the case of serpentine II, mass and charge balance was only achieved if all iron was disposed as $\mathrm{Fe}^{3+}$ in the octahedral layer. This is in agreement with Roqué-Rosell et al. (2016), who determined that most of iron in serpentine II is in the ferric form, by Fe K-edge XANES on samples from the saprolite horizon of the Falcondo Ni-laterite. This observation is coherent with Golightly and Arancibia (1979) who considered Fe to be in its oxidized form in serpentine II from Indonesia, and with Streit et al. (2012), who concluded that only the substitution of $\mathrm{Fe}^{3+}$ in octahedral sites in serpentine from Oman could explain the compositions they observed.

Thermodynamic calculations were carried out with the MEDUSA software package (Puigdomènech 2010), based on chemical equilibrium, and PHREEQC v.3 (Parkhurst and Appelo 2012). Thermodynamic data from Thermochimie v.9 database (Giffaut et al. 2014) were used in the calculations. Its domain of application is mainly within a $\mathrm{pH}$ range of 6 to 13, Eh of -0.5 to $+0.5 \mathrm{~V}$ and temperatures below $80^{\circ} \mathrm{C}$. $\mathrm{Si}, \mathrm{Ni}, \mathrm{Mg}$, and $\mathrm{Fe}$ aqueous speciation has been calculated considering the aqueous species and corresponding $\log K^{0}$ values.

\section{Results and discussion}

\section{Mineralogy and chemistry of $\mathrm{Fe}-\mathrm{Ni}$-serpentine in the saprolite horizon}

The X-ray powder diffractograms indicate that the saprolite samples are mostly composed by serpentine (Figs. $1 \mathrm{a}-\mathrm{c}$ and $2 \mathrm{a}-\mathrm{d}$ ) and minor goethite (Figs. 2a-c). Variable amounts of olivine and pyroxene relicts are detected in the Yamanigüey and Loma Ortega samples (Figs. 2a, b). In addition, minor quartz is found in the two Loma Caribe samples (Figs. 2c, b), which is interpreted to be precipitated during weathering. Examination of one sample from Loma Ortega under the Transmission Electron Microscope confirmed that it consists mostly of lizardite with very few chrysotile tubes.

\section{Fig. 1}

Location of the Ni-laterite deposits studied in the Caribbean, schematic geological maps and field photographs depicting the mining pits of Yamanigüey, in Cuba (a), and Loma Caribe (b) and Loma Ortega (c) in the Dominican Republic 


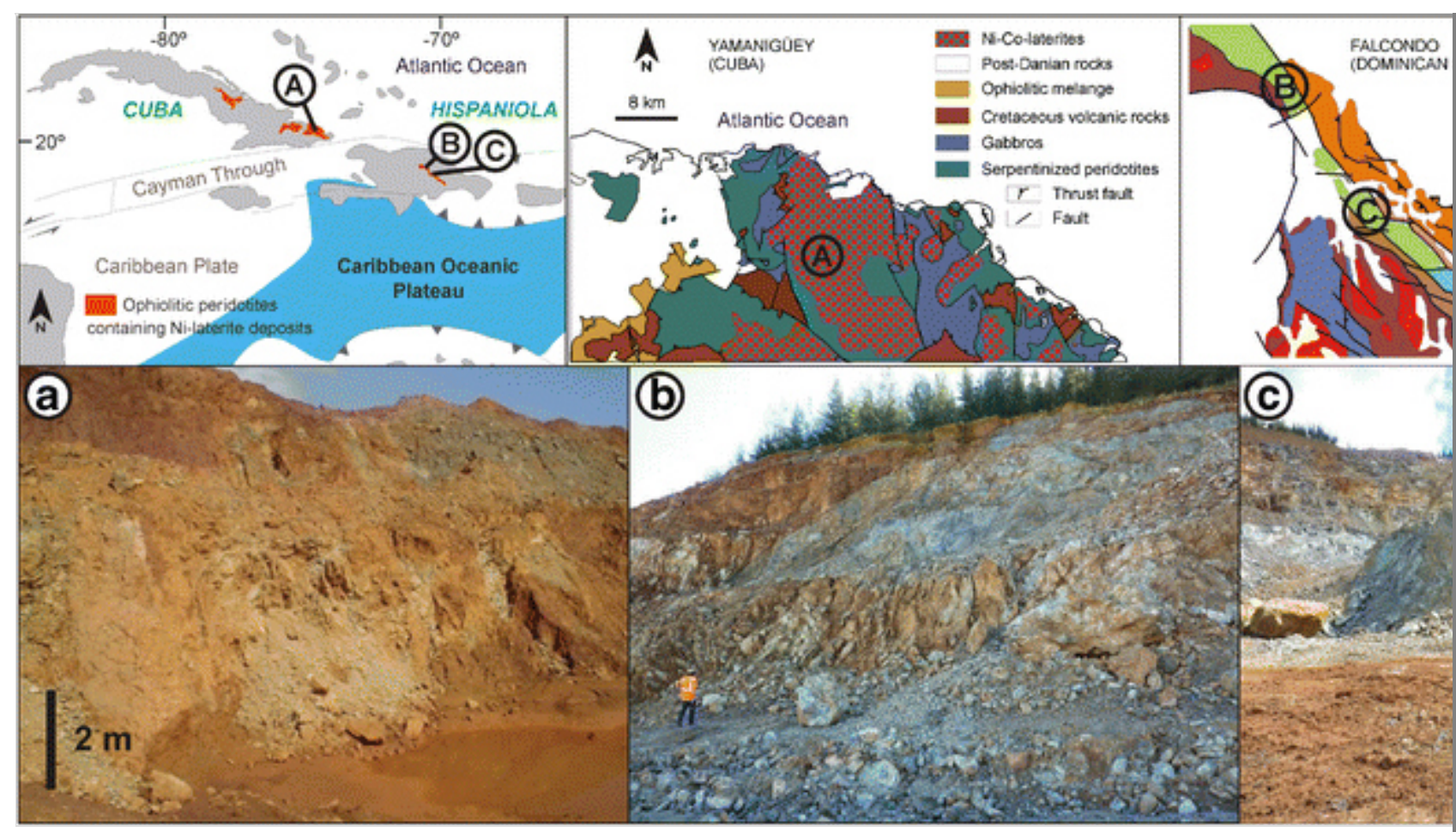

Fig. 2

Powder X-ray diffractograms of saprolite from Yamanigüey (a), Loma Ortega (b), and Loma Caribe (c, d). Mineral abbreviations from Whitney and Evans (2010) 


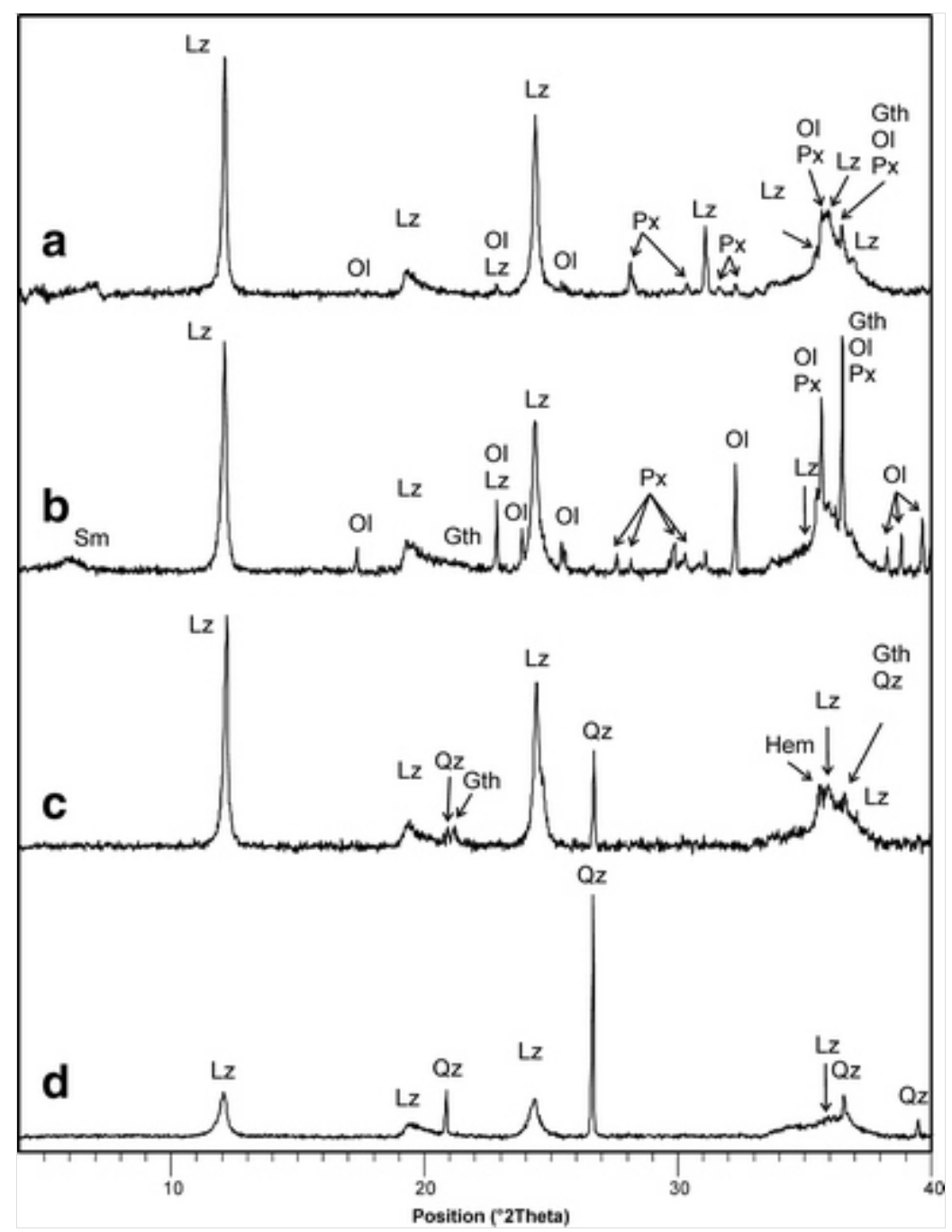

AQ9

Observations under the optical microscope show that serpentine forms yellowish rims around brown, rounded, silicified Fe-oxyhydroxide cores, and fills micron-thick veinlets (Figs. $3 \mathrm{a}-\mathrm{d}$ ). The examination under SEM confirms that serpentine is $\mathrm{Fe}-\mathrm{Ni}$ rich and therefore can be labeled as serpentine II. These textures are in agreement with the formation model described by Trescases (1973, 1979) and Streit et al. (2012). Trescases (1973), in New Caledonia, observed that serpentine in unweathered, serpentinized peridotite (serpentine I) was colorless, whereas serpentine in the saprolite (serpentine II) was strongly colored by Fe hydroxides, despite showing the mesh texture intact. Furthermore, Trescases (1979), on saprolite fragments from various Ni-laterite localities, found that olivine, surrounded by serpentine in a mesh arrangement, was replaced by Fe-oxyhydroxides, and the serpentine mesh remained intact after olivine weathering. Streit et al. (2012), when studying carbonatized, serpentinized peridotites from Oman, described that Fe-rich secondary serpentine, formed from a primary Fe-poor serpentine, develops mesh textures around quartz and Fe-oxyhydroxide cores, 
which were formerly olivine fragments. The difference between Streit et al. (2012) and this study is that the serpentinite from Oman did not undergo weathering under lateritic conditions and therefore did not experiment $\mathrm{Ni}$ enrichment from an upper horizon. The secondary serpentine is Fe rich but with low $\mathrm{Ni}$ and comes from the alteration of a $\mathrm{Fe}$-poor serpentine precursor.

\section{Fig. 3}

Optical and scanning electron micrographs of typical yellowish serpentine II mesh texture surrounding brownish Fe-oxyhydroxide and quartz rounded aggregates of the saprolite horizon: a-b plane polarized light (a) and crossed polarized (b) image of serpentine II from Loma Ortega; c-d plane polarized light (c) and detail backscattered electron image (d) of serpentine II (Srp II) and silicified goethite (Gth) from Loma Caribe; e plane polarized light (left) and crossed polarized (right) images of primary pyroxene $(P x)$ and olivine $(O l)$ relicts crosscut and surrounded by yellowish serpentine II in the saprolite sample from Yamanigüey; f backscattered electron image depicting the high variation of $\mathrm{Fe}$ and $\mathrm{Ni}$ contents in serpentine II from Loma Ortega 


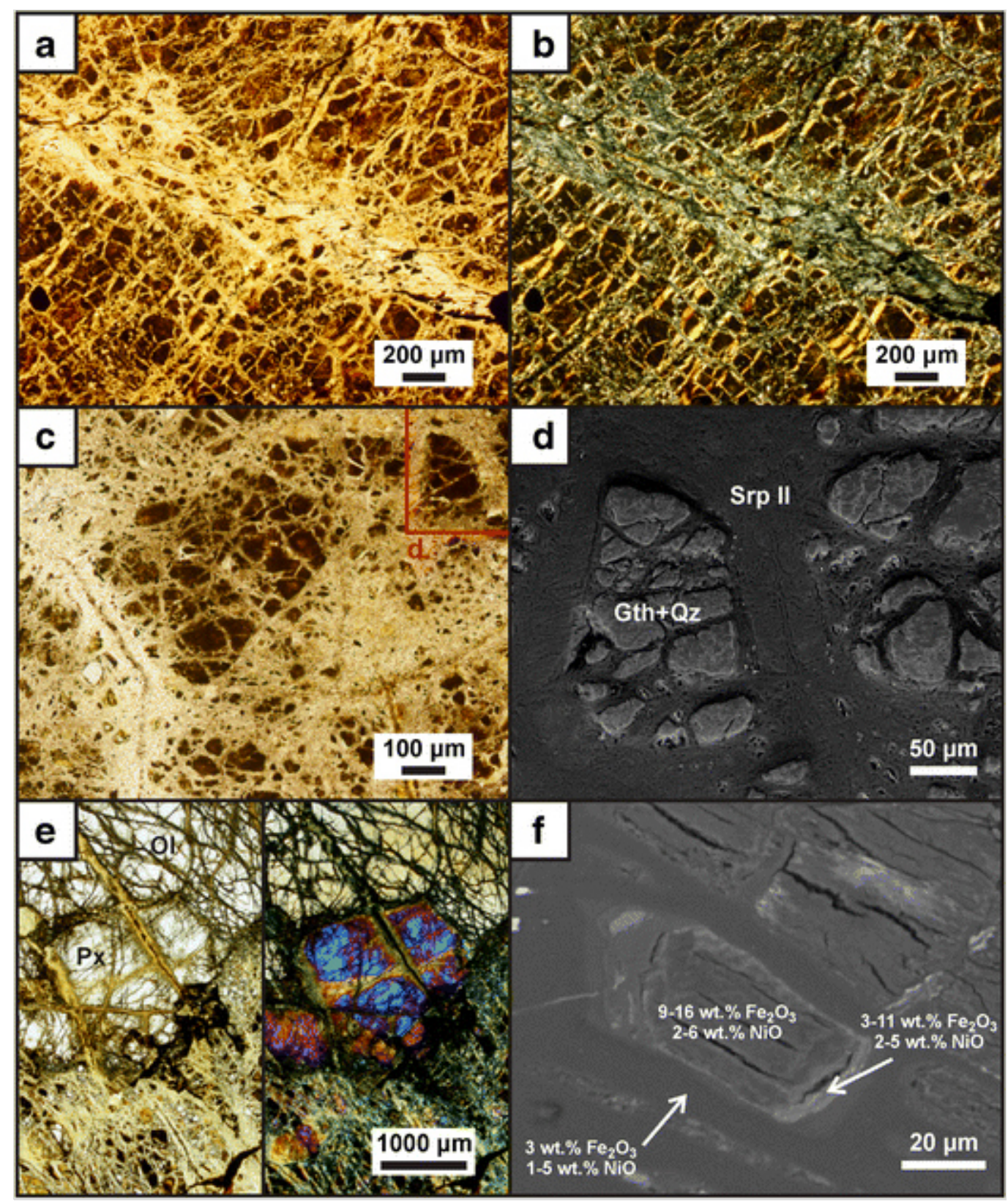

No traces of serpentine I were found in any of the four studied samples.

However, partially altered pyroxene and olivine relicts are in the Yamaniguiey sample (Fig. 3e), surrounded and crosscut by yellowish serpentine II (formerly serpentine I), along fractures and cleavage planes.

As seen in Figs. $3 \mathrm{f}$ and 4 and Table 1, EPMA analyses reveal a wide range of compositions with variable and high $\mathrm{Ni}$ and $\mathrm{Fe}$ contents across the samples. A total of 14 EPMA serpentine II analyses from the Yamanigüey sample show a variation from 5.26 to $13.48 \mathrm{wt} . \% \mathrm{Fe}_{2} \mathrm{O}_{3}\left(0.19-0.57\right.$ apfu $\left.\mathrm{Fe}^{3+}\right)$ and from 1.30 to $7.67 \mathrm{wt} . \% \mathrm{NiO}(0.06-0.39 \mathrm{apfu} \mathrm{Ni})$, and the average structural formula is $\mathrm{Mg}_{2.40} \mathrm{Fe}^{3+}{ }_{0.35} \mathrm{Ni}_{0.11} \mathrm{Si}_{1.92} \mathrm{O}_{5}(\mathrm{OH})_{4}$. Twenty-three EPMA serpentine II analyses from the Loma Ortega sample show Fe contents from 2.23 to 15.59 wt. $\% \mathrm{Fe}_{2} \mathrm{O}_{3}\left(0.08-0.57\right.$ apfu $\left.\mathrm{Fe}^{3+}\right)$ and $\mathrm{Ni}$ contents between 1.99 and 4.72 wt.\% $\mathrm{NiO}(0.08-0.19$ apfu Ni). The average structural formula of 
serpentine II from Loma Ortega is $\mathrm{Mg}_{2.50} \mathrm{Ni}_{0.13} \mathrm{Fe}^{3+}{ }_{0.24} \mathrm{Si}_{2.00} \mathrm{O}_{5}(\mathrm{OH})_{4}$. Thirty-nine EPMA serpentine II analyses were carried out in the two Loma Caribe samples. Serpentine II has 3.84-13.51 wt.\% $\mathrm{Fe}_{2} \mathrm{O}_{3}(0.14-0.50$ apfu $\mathrm{Fe}^{3+}$ ) and 1.75-7.00 wt.\% NiO (0.07-0.28 apfu Ni), with an average structural formula of $\mathrm{Mg}_{2.54} \mathrm{Fe}^{3+}{ }_{0.13} \mathrm{Ni}_{0.13} \mathrm{Si}_{1.95} \mathrm{O}_{5}(\mathrm{OH})_{4}$. These $\mathrm{Ni}$ and $\mathrm{Fe}$ contents are higher than those of serpentine I from samples of less weathered saprolite rocks collected at greater depths in the Ni-laterite profiles of Yamanigüey, Loma Ortega and Loma Caribe (Fig. 4). The composition of serpentine I from Yamanigüey ranges from 3.55 to 5.81 wt.\% FeO (0.14-0.24 apfu $\mathrm{Fe}^{2+}$ ) and from 0.10 to $0.34 \mathrm{wt} . \% \mathrm{NiO}$ (below 0.01 apfu Ni), and the average structural formula from 10 analyses is $\mathrm{Mg}_{2.73} \mathrm{Fe}^{2+}{ }_{0.07} \mathrm{Ni}_{0.02} \mathrm{Si}_{2.11} \mathrm{O}_{5}(\mathrm{OH})_{4}$. Serpentine I from Loma Ortega has $1.37-1.87$ wt. \% FeO (0.06-0.08 apfu Fe $\left.{ }^{2+}\right)$ and $0.15-0.53$ wt.\% NiO (0.01-0.02 apfu $\mathrm{Ni}$ ), and the average structural formula from 12 analyses is $\mathrm{Mg}_{2.63} \mathrm{Fe}^{2+}{ }_{0.24} \mathrm{Ni}_{0.01} \mathrm{Si}_{1.99} \mathrm{O}_{5}(\mathrm{OH})_{4}$. In addition, one analysis of serpentine I from Loma Caribe was obtained, with $2.91 \mathrm{wt} . \% \mathrm{FeO}\left(0.11\right.$ apfu $\left.\mathrm{Fe}^{2+}\right)$ and 0.62 wt.\% $\mathrm{NiO}(0.02 \mathrm{apfu} \mathrm{Ni})$ and the corresponding structural formula $\mathrm{Mg}_{2.67} \mathrm{Fe}_{0.11}^{2+} \mathrm{Ni}_{0.02} \mathrm{Si}_{2.06} \mathrm{O}_{5}(\mathrm{OH})_{4}$.

\section{Fig. 4}

Comparison between the major octahedral elements (Ni-Fe (a); $\mathrm{Ni}-\mathrm{Mg}(\mathbf{b})$; $\mathrm{Fe}-\mathrm{Mg}(\mathbf{c}) ; \mathrm{Ni}+\mathrm{Fe}-\mathrm{Mg}(\mathbf{d}))$ in serpentine II of the studied samples from Yamanigüey, Loma Ortega, and Loma Caribe, compared with serpentine I from other samples of the same occurrences, and the data of serpentines I and II from Indonesia (Golightly and Arancibia 1979; Chen et al. 2004), and from New Caledonia (Pelletier 1996; Chen et al. 2004). In (a), the curves indicate the general trend of the analyses obtained in serpentines II from Yamanigüey (red), Loma Ortega (yellow), and Loma Caribe (blue), and the corresponding arrows mark the Ni-Fe-enrichment paths between serpentines I and II in each deposit 

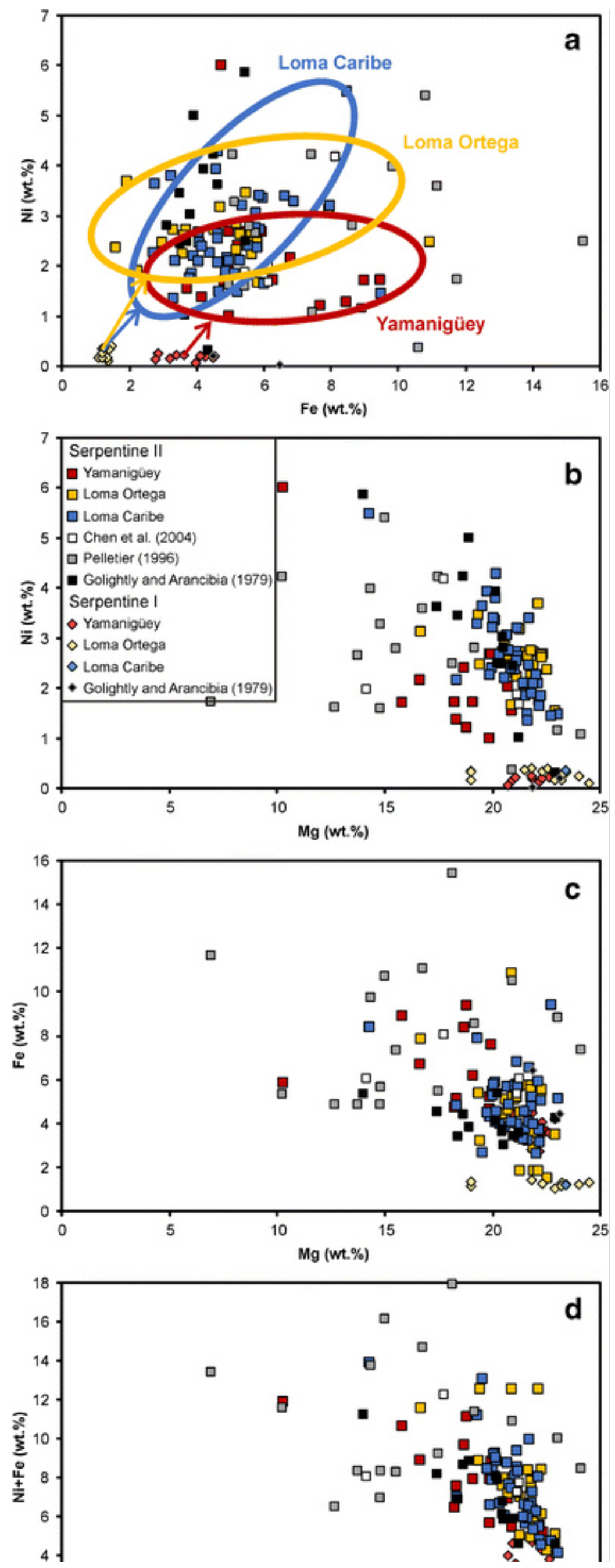
Table 1

Representative analyses obtained by EPMA in Fe-Ni-serpentines from Loma Orte Yamanigüey (Cuba) in weight percent and corresponding structural formulae calculated c AQ11

\begin{tabular}{|l|l|l|l}
\hline Locality & Loma Ortega & Loma Caribe & Yam
\end{tabular}

\begin{tabular}{|l|l|l|l|l|l|l|l|l|l|l|l|l} 
Label & LO-28 & LO-34 & LO-17 & LC-151 & LC-107 & LC-112 & YAM-9 & YAN
\end{tabular}

\begin{tabular}{|c|c|c|c|c|c|c|c|c|}
\hline $\mathrm{SiO}_{2}$ & 38.56 & 41.86 & 44.79 & 41.54 & 38.39 & 41.78 & 40.47 & $31.7 \xi$ \\
\hline $\mathrm{TiO}_{2}$ & $<0.01$ & 0.01 & $<0.01$ & 0.02 & $<0.01$ & $<0.01$ & $<0.01$ & $<0.0$ \\
\hline $\mathrm{Al}_{2} \mathrm{O}_{3}$ & 0.02 & $<0.01$ & 0.07 & 0.02 & 0.02 & 0.02 & 0.01 & 0.01 \\
\hline $\mathrm{Cr}_{2} \mathrm{O}_{3}$ & 0.01 & 0.01 & $<0.01$ & 0.04 & 0.02 & 0.02 & 0.05 & 0.03 \\
\hline $\mathrm{Fe}_{2} \mathrm{O}_{3}$ & 15.59 & 6.67 & 2.23 & 3.84 & 6.22 & 12.07 & 5.26 & 12.80 \\
\hline $\mathrm{MnO}$ & 0.08 & 0.11 & 0.04 & $<0.01$ & 0.05 & 0.07 & 0.02 & 0.07 \\
\hline $\mathrm{CoO}$ & 0.03 & $<0.01$ & $<0.01$ & 0.07 & 0.01 & 0.02 & $<0.01$ & $<0.0$ \\
\hline $\mathrm{MgO}$ & 32.12 & 35.19 & 37.29 & 38.14 & 32.88 & 23.61 & 36.98 & 26.1: \\
\hline $\mathrm{NiO}$ & 2.15 & 3.27 & 3.49 & 1.91 & 2.91 & 7.00 & 2.00 & 2.21 \\
\hline $\mathrm{CaO}$ & 0.04 & 0.03 & 0.01 & $<0.01$ & 0.12 & 0.29 & 0.02 & 0.06 \\
\hline $\mathrm{Na}_{2} \mathrm{O}$ & 0.01 & 0.01 & 0.03 & $<0.01$ & 0.02 & 0.15 & $<0.01$ & $<0.0$ \\
\hline $\mathrm{K}_{2} \mathrm{O}$ & $<0.01$ & $<0.01$ & $<0.01$ & $<0.01$ & $<0.01$ & 0.09 & $<0.01$ & 0.03 \\
\hline Total & 88.61 & 87.17 & 87.95 & 85.58 & 80.65 & 85.12 & 84.81 & 73.05 \\
\hline $\mathrm{Si}$ & 1.868 & 2.000 & 2.081 & 1.992 & 1.984 & 2.109 & 1.971 & 1.870 \\
\hline $\mathrm{Ti}$ & - & 0.000 & - & 0.001 & - & - & - & - \\
\hline $\mathrm{Al}$ & 0.001 & - & 0.004 & 0.001 & 0.001 & 0.001 & 0.001 & 0.001 \\
\hline $\mathrm{Cr}$ & 0.000 & 0.000 & - & 0.002 & 0.001 & 0.001 & 0.002 & 0.001 \\
\hline $\mathrm{Fe}^{3+}$ & 0.568 & 0.240 & 0.078 & 0.139 & 0.242 & 0.459 & 0.193 & 0.56 \\
\hline Mn & 0.003 & 0.005 & 0.001 & - & 0.002 & 0.003 & 0.001 & 0.00 \\
\hline Co & 0.001 & - & - & 0.003 & 0.001 & 0.001 & - & - \\
\hline $\mathrm{Mg}$ & 2.319 & 2.506 & 2.582 & 2.726 & 2.533 & 1.777 & 2.685 & $2.29<$ \\
\hline
\end{tabular}

Selected data from Indonesia (Golightly and Arancibia 1979) and New Caledonia (Pe apfu atoms per formula unit (atomic concentration) 


\begin{tabular}{|l|l|l|l|l|l|l|l|l|}
\hline \multicolumn{1}{|c|}{ Label } & LO-28 & LO-34 & LO-17 & LC-151 & LC-107 & LC-112 & YAM-9 & YAN \\
\hline $\mathrm{Ni}$ & 0.084 & 0.126 & 0.130 & 0.074 & 0.121 & 0.284 & 0.078 & $0.10 \leftleftarrows$ \\
\hline $\mathrm{Ca}$ & 0.002 & 0.001 & 0.001 & - & 0.007 & 0.016 & 0.001 & $0.00<$ \\
\hline $\mathrm{Na}$ & 0.001 & 0.001 & 0.003 & - & 0.002 & 0.015 & - & - \\
\hline $\mathrm{K}$ & - & - & - & - & - & 0.006 & - & $0.00 \%$ \\
\hline
\end{tabular}

Selected data from Indonesia (Golightly and Arancibia 1979) and New Caledonia (Pe $a p f u$ atoms per formula unit (atomic concentration)

The high Fe contents in serpentine could be explained by contamination of the analyses by micro- or nano-magnetite inclusions. Magnetite usually forms during serpentinization of ultramafic rocks: olivine in the presence of water is transformed into serpentine and ferroan brucite, which in turn can react with aqueous silica to become serpentine and magnetite (Sleep et al. 2004).

However, magnetite was not detected by powder XRD or when examining the samples under SEM and TEM. In addition, serpentines are not stoichiometric and displayed vacancies in the octahedral layer (possibly as a consequence of $\mathrm{Mg}^{2+}-\mathrm{Fe}^{3+}$ substitution). This non-stoichiometry was also observed by Goligthly and Arancibia (1979) and Orberger et al. (1990). Therefore, Fe is considered to be contained in the octahedral layer of serpentine. The relationship between the octahedral cations $(\mathrm{Mg}, \mathrm{Ni}$, and $\mathrm{Fe})$ is plotted in Fig. 4, which includes data from serpentine I and II from Yamanigüey, Loma Ortega and Loma Caribe and data from Golightly and Arancibia (1979), Pelletier (1996), and Chen et al. (2004). According to Fig. 4a, Ni and Fe in serpentine II from the Caribbean are positively correlated. This correlation indicates that serpentine II is enriched in $\mathrm{Ni}$ and $\mathrm{Fe}$ with respect to serpentine I, and therefore the incorporation of $\mathrm{Fe}$ and $\mathrm{Ni}$ can be linked to weathering. Furthermore, the slope is steeper in Loma Caribe than in Loma Ortega and Yamaniguiey. This indicates that Ni increases more rapidly than $\mathrm{Fe}$ in serpentine II from Loma Caribe than in the other two occurrences. This was also observed by Golightly and Arancibia (1979) in serpentine II from Indonesia. The results are comparable to serpentine II from the literature, although serpentine II from Indonesia have a narrower range of Fe contents (Golightly and Arancibia 1979), whereas those from New Caledonia display a 
wider range of Fe and Ni contents (Pelletier 1996).

Figure $4 \mathrm{~b}-\mathrm{d}$ displays a negative correlation between $\mathrm{Ni}$ and $\mathrm{Mg}$, between $\mathrm{Fe}$ and $\mathrm{Mg}$, and between $\mathrm{Ni}+\mathrm{Fe}$ and $\mathrm{Mg}$, respectively; this correlation is better defined in the $\mathrm{Ni}+\mathrm{Fe}-\mathrm{Mg}$ diagram (Fig. 4d). The steepest slopes are for serpentine II from Loma Caribe (Fig. 4b) and Loma Ortega (Fig. 4b, c). The $\mathrm{Ni}-\mathrm{Mg}$ data from Loma Ortega and Loma Caribe are more similar to those of Golightly and Arancibia (1979) and Pelletier (1996) than those from Yamanigüey (Fig. 4b). In contrast, the Fe-Mg data from Yamanigüey are close to those of Pelletier (1996) whereas Fe-Mg data from Loma Ortega and Loma Caribe are similar to those of Golightly and Arancibia (1979). The negative correlation confirms that $\mathrm{Ni}$ and $\mathrm{Fe}$ exchange for $\mathrm{Mg}$ in the octahedral layer of the serpentine structure.

\section{Thermodynamic modeling}

Thermodynamic data selection for serpentines

The solubility constants for serpentine II depend on their composition in terms of $\mathrm{Mg}, \mathrm{Ni}$, and $\mathrm{Fe}(\mathrm{III})$ contents. These serpentines can be described as a solid solution between three end members: a pure $\mathrm{Mg}$, a pure $\mathrm{Ni}$ and a pure $\mathrm{Fe}$ (III) serpentine. Assuming that the solid solution is behaving ideally (Boschetti and Toscani 2008), the equilibrium constant of serpentine of a given composition can be calculated following Eq. 5, where $K_{i}$ is the equilibrium constant of end member $i$ (Mg-, Ni-, or $\mathrm{Fe}(\mathrm{III})$-end members) and $\chi_{i}$, the molar fraction of this end member in the serpentine.

$$
\log K^{*}=\sum_{i=1}^{i=n} \chi_{i} \log K_{i}+\sum_{i=1}^{i=n} \chi_{i} \log \chi_{i}
$$

Lizardite $\left(\mathrm{Mg}_{3} \mathrm{Si}_{2} \mathrm{O}_{5}(\mathrm{OH})_{4}\right)$ is taken as the $\mathrm{Mg}$-end member. ThermoChimie v.9 database (Giffaut et al. 2014) provides a $\log K^{0}$ value of $33.100( \pm 0.900)$ for reaction 6 at $25{ }^{\circ} \mathrm{C}$ and 1 bar. Thermoddem database (Blanc et al. 2012) gives a $\log K^{0}$ value of 32.82 for the same reaction, which falls within the uncertainty range of data of ThermoChimie. Golightly (1981) reported a $\Delta G_{\mathrm{f}}^{0}$ for lizardite of $-4036.51 \mathrm{~kJ} / \mathrm{mol}$ from data of Luce (1971), very similar to the value provided by Wilson et al. (2006) of $-4040.2461 \mathrm{~kJ} / \mathrm{mol}$. Blanc et al. (2015) reported a $\Delta H_{f}^{0}$ value of $-4362.00 \mathrm{~kJ} / \mathrm{mol}( \pm 3.0)$ and a $S^{0}$ of $216.30 \mathrm{~J} \mathrm{~K}^{-1} \mathrm{~mol}^{-1}( \pm 0.8)$ for lizardite, both values from Evans (2004) and Robie and Hemingway (1995). The $\log K^{0}$ (reaction 6) values calculated from these thermodynamic and auxiliary data of ThermoChimie v.9 database are 
$32.45,31.79$, and 33.08 , respectively, being close to the value selected from ThermoChimie.

$$
\mathrm{Mg}_{3} \mathrm{Si}_{2} \mathrm{O}_{5}(\mathrm{OH})_{4}+6 \mathrm{H}^{+}=3 \mathrm{Mg}^{2+}+2 \mathrm{H}_{4} \mathrm{SiO}_{4}+\mathrm{H}_{2} \mathrm{O}
$$

The Ni-end member is népouite $\left(\mathrm{Ni}_{3} \mathrm{Si}_{2} \mathrm{O}_{5}(\mathrm{OH})_{4}\right)$. Few $\log K$ data are reported in literature for népouite solubility (reaction 7) at $25{ }^{\circ} \mathrm{C}$ and 1 bar. Golightly (1981) provided a $\Delta G_{f}^{0}$ for népouite of $-2881.93 \mathrm{~kJ} / \mathrm{mol}$, from extrapolation of experimental data. Boschetti and Toscani (2008) selected the $\Delta G_{f}^{0}$ value of $-2893.24 \mathrm{~kJ} / \mathrm{mol}$ and $\log K^{0}$ (reaction 7 ) of 16.80 of Mondesir and Decarreau (1987), which came from solubility data of a synthetic népouite measured at $25{ }^{\circ} \mathrm{C}$. Galí et al. (2012) estimated a $\Delta G_{f}^{0}$ value of $-2866.69 \mathrm{~kJ} / \mathrm{mol}$ following Nriagu (1975) approach from which they calculated a $\log K^{0}$ (reaction 7 ) of 21.4688.

$$
N i_{3} \mathrm{Si}_{2} \mathrm{O}_{5}(\mathrm{OH})_{4}+6 \mathrm{H}^{+}=3 \mathrm{Ni}^{2+}+2 \mathrm{H}_{4} \mathrm{SiO}_{4}+\mathrm{H}_{2} \mathrm{O}
$$

Following previous authors (Wicks and Plant 1979; Evans 2008; Evans et al. 2009), Streit et al. (2012) proposed a pure Fe(III)-end member of formula $\mathrm{Fe}_{2}^{3+} \mathrm{Si}_{2} \mathrm{O}_{5}(\mathrm{OH})_{4}$, which differs from greenalite $\left(\mathrm{Fe}_{3}^{2+}{ }_{3} \mathrm{Si}_{2} \mathrm{O}_{5}(\mathrm{OH})_{4}\right)$ in the sense that $\mathrm{Fe}$ is + III instead of + II. Thermodynamic data of $\mathrm{Fe}(\mathrm{III})$-serpentine in the literature is scarce. As experimentally derived thermodynamic data of $\mathrm{Fe}(\mathrm{III})$-serpentine were not available, Klein et al. (2009) reported a $\Delta G_{f}^{0}$ value of $-2963.77 \mathrm{~kJ} / \mathrm{mol}$, estimated with the Chermak and Rimstidt (1989) polyhedral sum approach. No $\log K^{0}$ values for reaction 8 have been found in literature.

$$
\mathrm{Fe}^{3+}{ }_{2} \mathrm{Si}_{2} \mathrm{O}_{5}(\mathrm{OH})_{4}+6 \mathrm{H}^{+}=2 \mathrm{Fe}^{3+}+2 \mathrm{H}_{4} \mathrm{SiO}_{4}+\mathrm{H}_{2} \mathrm{O}
$$

Available $\Delta G_{f}^{0}$ values for népouite and Fe(III)-serpentine in the literature are estimated following different methods. The estimations proposed in Nriagu (1975) and Chermak and Rimstidt (1989) are statistical methods that describe the thermodynamic functions as a linear combination of one or several chemical and physical variables (Blanc et al. 2015). However, there are other methods that estimate thermodynamic values by using empirical parameters in the prediction calculations such as the Pauling electronegativity (Blanc et al. 2015). One of these methods was proposed by Vieillard (2000, 2002 ) which estimates the Gibbs free energy from the electronegativity 
difference concept for hydrated and dehydrated clays. Recently, Blanc et al. (2015) presented a model for estimating the enthalpy of formation based on site specific interactions that uses an electronegativity scaling of the excess energy (Viellard 1994a, b) and a model for predicting entropies, based on the polyhedral decomposition method.

In order to increase the internal consistency of the database used in this study, $\Delta G_{f}^{0}$ values for népouite and $\mathrm{Fe}(\mathrm{III})$-serpentine have been estimated following the approach of Blanc et al. (2015). $\Delta \mathrm{G}_{\mathrm{f}}^{0}$ values estimated by interpreting equations of Blanc et al. (2015) and using auxiliary data from Thermochimie v.9 were $-2884.8 \mathrm{~kJ} / \mathrm{mol}$ for népouite and $-2894.7 \mathrm{~kJ} / \mathrm{mol}$ for $\mathrm{Fe}(\mathrm{III})$ serpentine. Given that $\Delta G_{f}^{0}$ values for kaolinite and greenalite estimated with Blanc et al. (2015) were -3794.01 and $-2996.50 \mathrm{~kJ} / \mathrm{mol}$ respectively, which only differ 0.3 and $6 \mathrm{~kJ} / \mathrm{mol}$ from values reported in ThermoChimie v.9 for kaolinite $(-3793.715 \pm 4.100 \mathrm{~kJ} / \mathrm{mol})$ and greenalite $(-3002.910 \mathrm{~kJ} / \mathrm{mol}$, uncertainty not specified), an uncertainty of $10 \mathrm{~kJ}$ has been assigned to the estimated $\Delta G_{f}^{0}$ values. $\log K$ for reactions 7 and 8 calculated using auxiliary data from ThermoChimie v. 9 were $19 \pm 4$ and $-1 \pm 4$, respectively.

Solubility constants for all serpentine II analyses were then calculated using Eq. 5. Calculated values range from $31.4 \pm 0.9$ to $25 \pm 1$ and correspond to those samples with higher and lower $\mathrm{Mg}$ respectively. Most of $\log K$ values are in the range between 28.0 and 32.0, with an average of $29 \pm 1$ (Fig. $5 \mathrm{a}$ ). No significant differences in $\log K^{0}$ values have been observed between serpentines of Loma Ortega, Loma Caribe and Yamanigüey, which is coherent with the low variation of serpentine compositions among the three localities (Fig. 5 b). In addition, $\log K^{0}$ values calculated for serpentines II from Indonesia reported in Golightly and Arancibia (1979) are also within the range of values calculated for Caribbean serpentines, and similar to the values calculated for the samples from New Caledonia of Pelletier (1996). The minimum $\log K^{0}$ value obtained in a serpentine from Pelletier (1996) corresponds to an analysis of a serpentine II with extremely low Mg content in comparison with the other samples provided by Pelletier (1996). Taking into account that calculated $\log K$ values for the different serpentines are all within a narrow range $(31.4 \pm .0 .9$ to $25 \pm 1)$, only three samples have been selected to carry out the thermodynamic calculations.

\section{Fig. 5}

a Histogram showing the $\log K^{0}$ values calculated for the serpentine II compositions analyzed with EPMA. b Average, minimum, and maximum $\log K^{0}$ 
values calculated for serpentine compositions of Loma Ortega, Loma Caribe, and Yamanigüey Ni-laterites and for serpentine compositions from Indonesia and New Caledonia (Golightly and Arancibia 1979; Pelletier 1996, respectively)
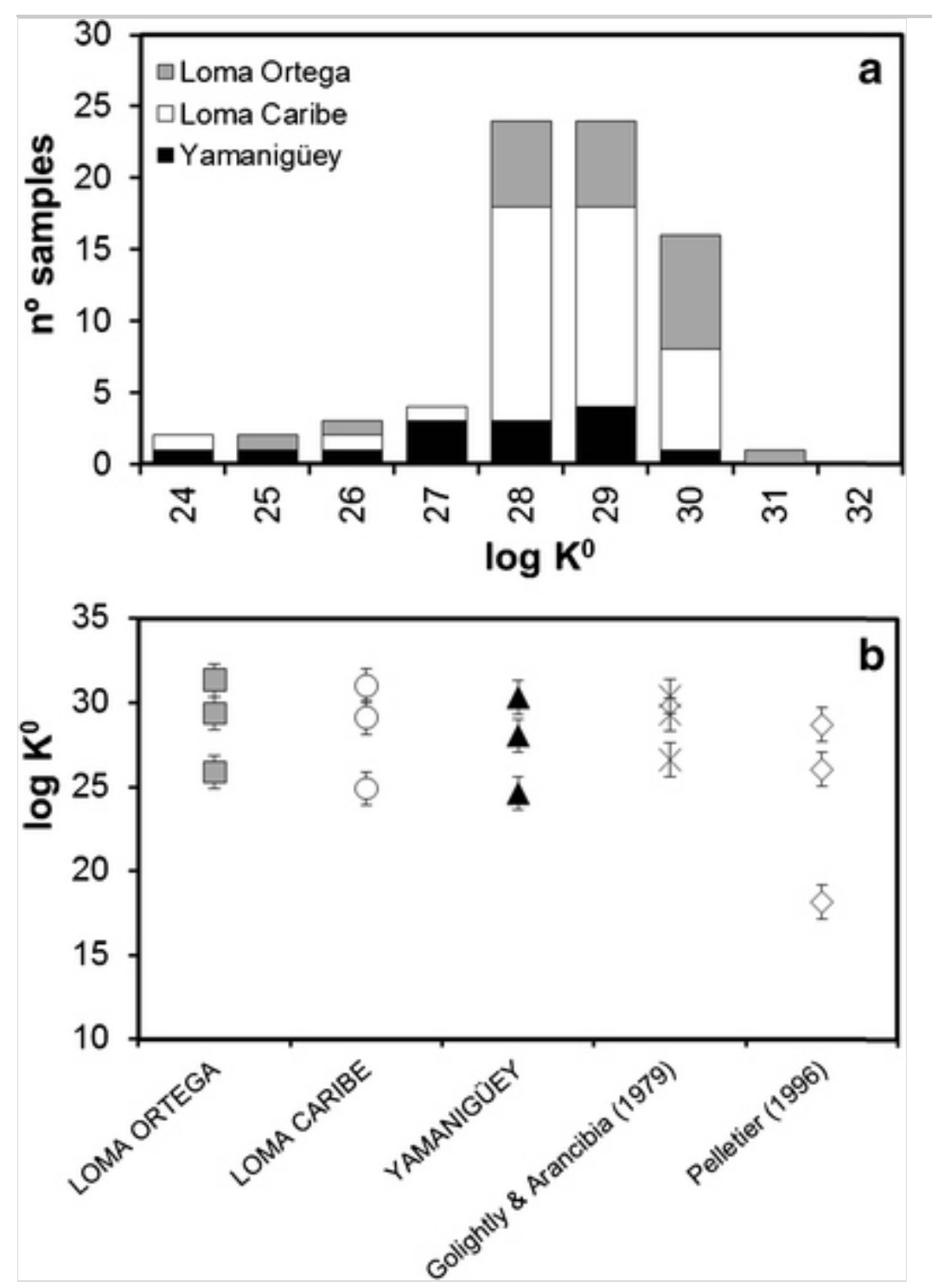

The analysis LC-107 from Loma Caribe $\left.\left(\mathrm{Mg}_{2.625} \mathrm{Fe}^{3+}{ }_{0.166} \mathrm{Ni}_{0.126}\right) \mathrm{Si}_{2} \mathrm{O}_{5}(\mathrm{OH})_{4}\right)$ with a $\log K^{0}$ of $29.4 \pm 0.9$ has been selected as representative of the most common serpentine composition. The analysis LO-17 from Loma Ortega $\left(\left(\mathrm{Mg}_{2.776} \mathrm{Fe}^{3+}{ }_{0.056} \mathrm{Ni}_{0.140}\right) \mathrm{Si}_{2} \mathrm{O}_{5}(\mathrm{OH})_{4}\right)$ and the analysis YAM-179 $\left(\left(\mathrm{Mg}_{2.321} \mathrm{Fe}^{3+}{ }_{0.382} \mathrm{Ni}_{0.106}\right) \mathrm{Si}_{2} \mathrm{O}_{5}(\mathrm{OH})_{4}\right)$ from Yamanigüey, have been selected as representative of the highest $(31.4 \pm 0.9)$ and the lowest $\log K^{0}(25 \pm 1)$, respectively.

Saprolite porewaters

Information on groundwater composition associated with the saprolite horizon is scarce. Landauro Sotelo (2008)provided chemical analyses of nine 
groundwater samples from the Falcondo Ni-laterite deposit (Dominican Republic). The samples are from groundwater flowing through the saprolite horizon (Table 2). $\mathrm{pH}$ values varies from 8.28 to 9.26 . The most abundant cations are $\mathrm{Mg}, \mathrm{Si}$, and $\mathrm{Na}$, with concentrations between 13 and $42 \mathrm{mg} / \mathrm{L}$ $\left(\sim 1 \times 10^{-3} \mathrm{M}\right), 25$ and $55 \mathrm{mg} / \mathrm{L}\left(\sim 4 \times 10^{-4} \mathrm{M}\right)$, and between 4 and $7 \mathrm{mg} / \mathrm{L}$ $\left(\sim 2 \times 10^{-4} \mathrm{M}\right)$, respectively. Nickel concentrations are between 2 $\left(4 \times 10^{-8} \mathrm{M}\right)$ and $120 \mu \mathrm{g} / \mathrm{L}\left(4 \times 10^{-6} \mathrm{M}\right)$ while iron concentrations are between 100 and $220 \mu \mathrm{g} / \mathrm{L}\left(2\right.$ to $\left.4 \times 10^{-6} \mathrm{M}\right)$. Bicarbonate concentration is about $100 \mathrm{mg} / \mathrm{L}\left(\sim 2 \times 10^{-3} \mathrm{M}\right)$ and $\mathrm{Cl}^{-}$concentrations are between 4 to $9 \mathrm{mg} / \mathrm{L}\left(\sim 2 \times 10^{-4} \mathrm{M}\right)$.

\section{Table 2}

Chemical water analyses of the Falcondo Ni-laterite (Dominican Republic) obtained frc Sotelo (2008)

\begin{tabular}{|l|l|l|l|l|l|l|l|l|}
\hline & $\mathbf{A 1 a}$ & \multicolumn{1}{|c|}{$\mathbf{A 2 a}$} & \multicolumn{1}{|c|}{$\mathbf{A 3 a}$} & \multicolumn{1}{|c|}{$\mathbf{A 4 a}$} & $\mathbf{A 5 a}$ & $\mathbf{A 6 a}$ & $\mathbf{A 7 a}$ & $\mathbf{A 8 a}$ \\
\hline $\mathrm{pH}$ & 8.57 & 9.07 & 8.82 & 8.76 & 8.73 & 8.28 & 9.17 & 8.89 \\
\hline $\mathrm{Na}$ & 4.09 & 6.12 & 6.86 & 5.03 & 6.26 & 7.21 & 4.85 & 6.57 \\
\hline $\mathrm{K}$ & 0.09 & 0.22 & 0.09 & 0.1 & 0.14 & 0.12 & 0.06 & 0.11 \\
\hline $\mathrm{Ca}$ & 1.62 & 7.85 & 1.04 & 0.74 & 0.81 & 0.63 & 1.65 & 1.06 \\
\hline $\mathrm{Mg}$ & 24.06 & 20.15 & 35.21 & 13.85 & 22.4 & 18.23 & 42.21 & 21.12 \\
\hline $\mathrm{Cl}$ & 5.1 & 7.29 & 7.29 & 5.83 & 5.83 & 4.37 & 8.74 & 5.83 \\
\hline $\mathrm{SO}_{4}^{2-}$ & 26.59 & 13.58 & 4.39 & 11.45 & 6.19 & 5.41 & 2.13 & 2 \\
\hline $\mathrm{HCO}_{3}{ }^{-}$ & 100.4 & 106.52 & 168.96 & 67.34 & 111.42 & 105.3 & 171.41 & 112.64 \\
\hline $\mathrm{SiO}_{2}$ & 35.89 & 32.02 & 54.82 & 26.5 & 27.1 & 26.31 & 48.92 & 26.74 \\
\hline $\mathrm{P}^{2}$ & 2.54 & 3.06 & 4.57 & 2.92 & 2.52 & 2.53 & 4.01 & 2.9 \\
\hline $\mathrm{Fe}$ & 0.2181 & 0.1968 & 0.1284 & 0.1243 & 0.1264 & 0.1468 & 0.1628 & 0.1004 \\
\hline $\mathrm{Mn}$ & 0.1288 & 0.07949 & 0.04374 & 0.0353 & 0.0244 & 0.01719 & 0.0188 & 0.0163 \\
\hline $\mathrm{Ni}$ & 0.1181 & 0.00887 & 0.02698 & 0.0178 & 0.01126 & 0.00253 & 0.02173 & 0.0162 \\
\hline
\end{tabular}

Concentrations are given in milligrams per liter

Speciation calculations using PHREEQC v.3 and the Thermochimie v.9 database (Giffaut et al. 2014) indicate that the ionic strength values of the groundwater are between $2.0 \times 10^{-3}$ and $5.0 \times 10^{-3} \mathrm{~mol} / \mathrm{L}$ (Fig. 6a). C, Cl, S, $\mathrm{N}$, and $\mathrm{P}$ are mostly forming $\mathrm{HCO}_{3}{ }^{-}, \mathrm{Cl}^{-}, \mathrm{SO}_{4}{ }^{2-}$, and $\mathrm{HPO}_{4}{ }^{2-}$, respectively, 
although they also form soluble complexes with $\mathrm{Mg}, \mathrm{Na}, \mathrm{Ca}$, and in minor amount with $\mathrm{Ni}$. $\mathrm{Ca}, \mathrm{K}, \mathrm{Na}$, and $\mathrm{Mg}$ are mostly presented in their free form as $\mathrm{Ca}^{2+}, \mathrm{K}^{+}, \mathrm{Na}^{+}$, and $\mathrm{Mg}^{2+}$ although they secondarily form aqueous complexes with $\mathrm{CO}_{3}{ }^{2-}$. Ni is mainly as free ion $\mathrm{Ni}^{2+}$ but also forming $\mathrm{Ni}(\mathrm{OH})_{2}(\mathrm{aq})$ and $\mathrm{Ni}\left(\mathrm{CO}_{3}\right)(\mathrm{aq})$ aqueous complexes. Since no redox data are available, the speciation of $\mathrm{Fe}$ cannot be computed. Calculated saturation indices show that the waters are near equilibrium with calcite and quartz (Fig. 6b).

\section{Fig. 6}

Ionic strength (mol/L) (a) and saturation indices of quartz and calcite (b) of each porewater sample listed in Table 2. Dotted line in (b) represents equilibrium

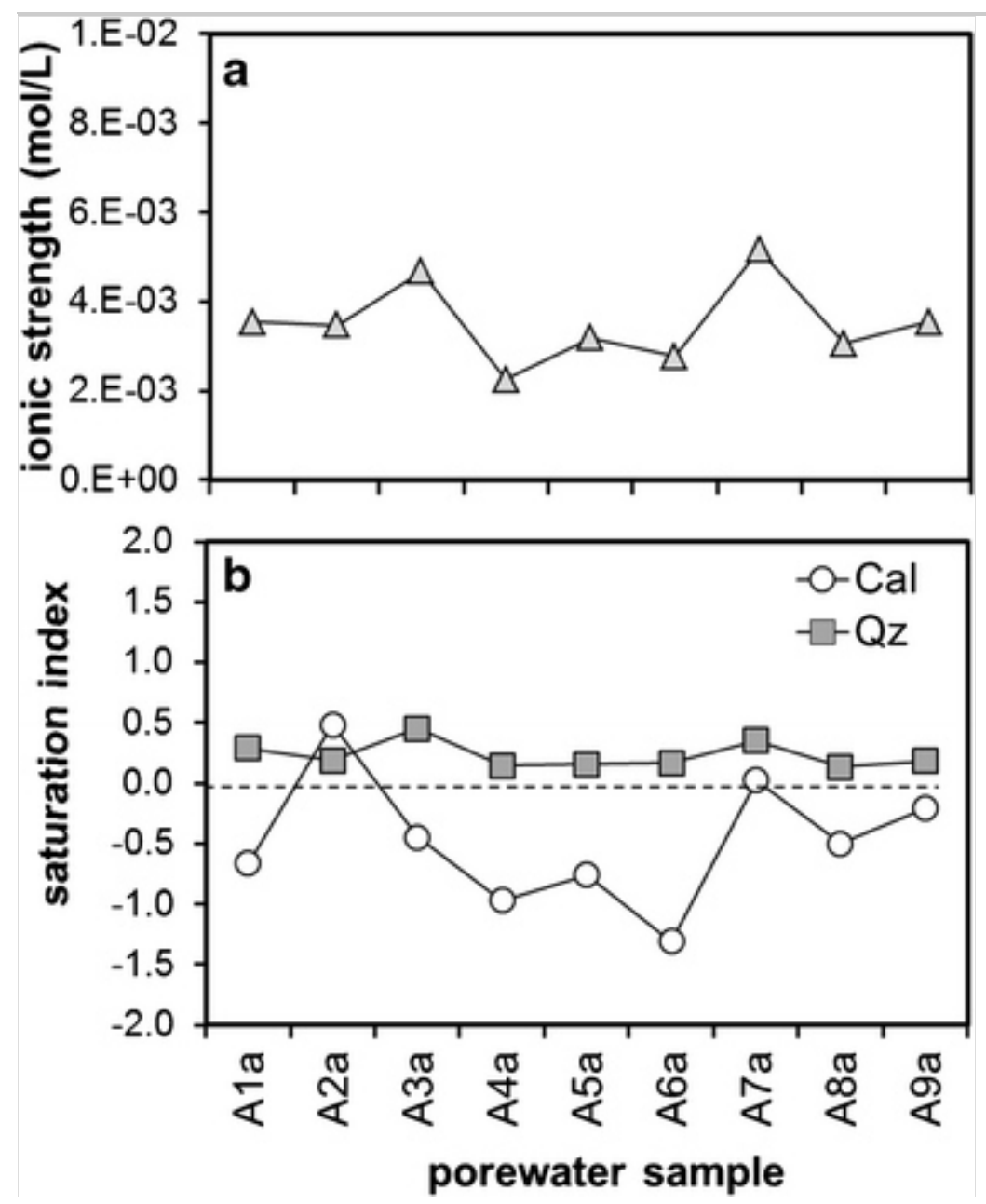

\section{Thermodynamic calculations}

Figure 7 shows the solubility of serpentines LC-107, LO-17 and YAM-179 in saprolite groundwaters. Solubilities, in terms of $\mathrm{Si}, \mathrm{Mg}, \mathrm{Fe}$, and $\mathrm{Ni}$ aqueous concentrations, have been calculated at $\mathrm{Eh}=0.4 \mathrm{~V}$ and $\mathrm{Eh}=-0.3 \mathrm{~V}$ with the corresponding $\log K^{0}$ values. Concentration of other major components such 
as carbonate has been considered equal to those of water sample A9a (Table 2 ), the groundwater with the highest $\mathrm{pH}$. Additionally, calculations have also been performed using porewater composition of sample A6a (lowest $\mathrm{pH}$ ) but no significant differences arised. The solubility curves are compared with $\mathrm{Si}$, $\mathrm{Mg}, \mathrm{Fe}$ and $\mathrm{Ni}$ concentrations measured in saprolite groundwaters from the Falcondo Ni-laterite.

\section{Fig. 7}

Solubility of LC-117, LO-17, and YAM-179 serpentines calculated assuming $\mathrm{Eh}=0.4 \mathrm{~V}$ and $\mathrm{Eh}=-0.3 \mathrm{~V}$ in porewaters of the Falcondo Ni-laterite compared to $\mathrm{Si}, \mathrm{Mg}, \mathrm{Fe}$, and $\mathrm{Ni}$ concentrations measured in porewater samples. Calculations using the following concentrations: $\left[\mathrm{SO}_{4}{ }^{2-}\right]_{\text {tot }}=2.0 \times 10^{-4} \mathrm{M}$; $\left[\mathrm{Cl}^{-}\right]_{\text {tot }}=2.0 \times 10^{-4} \mathrm{M} ;\left[\mathrm{CO}_{3}{ }^{2-}\right]_{\mathrm{tot}}=1.7 \times 10^{-3} \mathrm{M} ;\left[\mathrm{Ca}^{2+}\right]_{\mathrm{tot}}=3.1 \times 10^{-5} \mathrm{M}$; $\left[\mathrm{Mg}^{2+}\right]_{\text {tot }}=1.0 \times 10^{-3} \mathrm{M} ;\left[\mathrm{Si}^{4+}\right]_{\text {tot }}=3.6 \times 10^{-4} \mathrm{M} ;[\mathrm{Fe}]_{\text {tot }}=2.5 \times 10^{-6} \mathrm{M}$; $[\mathrm{Ni}]_{\text {tot }}=5.5 \times 10^{-7} \mathrm{M}$. Si, Mg, Fe, and Ni concentrations are allowed to vary in their corresponding solubility diagrams
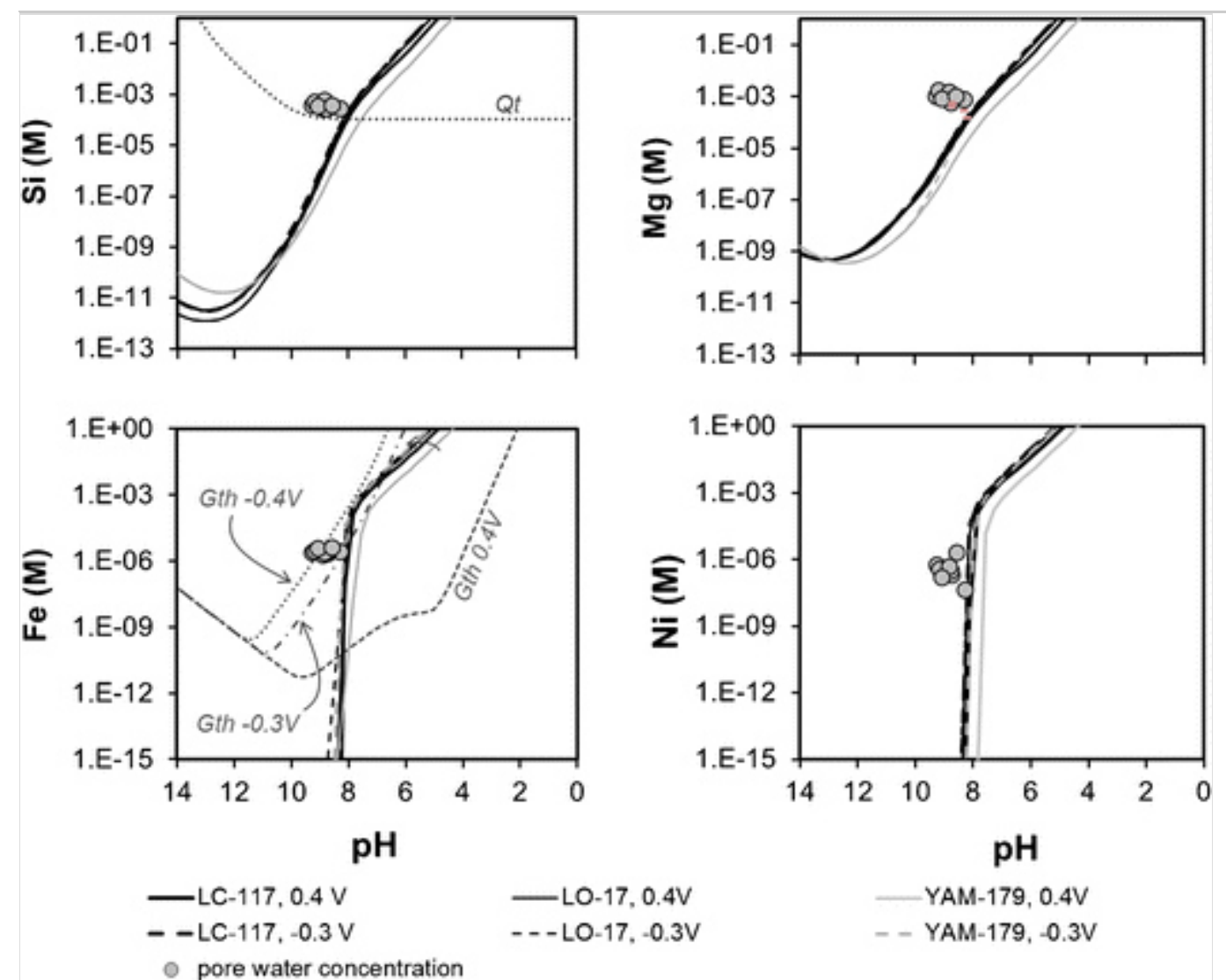

Solubility of serpentine decreases with an increase of $\mathrm{pH}$ due to changes on $\mathrm{Mg}, \mathrm{Si}, \mathrm{Fe}$, and $\mathrm{Ni}$ aqueous speciation towards aqueous species less stable in solution, which are $\mathrm{Mg}, \mathrm{Ni}$, and $\mathrm{Fe}$ carbonate and/or sulfate aqueous species at near neutral $\mathrm{pH}$ and $\mathrm{Mg}, \mathrm{Ni}$, and $\mathrm{Fe}$ aqueous hydroxides at higher $\mathrm{pH}$. The 
solubility of serpentine II varies over several orders of magnitude for small changes in $\mathrm{pH}$, when $\mathrm{pH}$ is in the range 7.5-8.5. This is evidence of the strong effect of slight variations in $\mathrm{pH}$ on serpentine II solubilities. No significant differences are observed between solubilities calculated at $\mathrm{Eh}=0.4 \mathrm{~V}$ and at $\mathrm{Eh}=-0.3 \mathrm{~V}$ except for serpentine YAM-179. This represents the serpentine with $\operatorname{lower} \log K^{0}$, and those with higher Fe(III) content. Solubility at $\mathrm{Eh}=0.4 \mathrm{~V}$ is lower than at $\mathrm{Eh}=-0.3 \mathrm{~V}$, indicating that stability of serpentine increases when redox values become more oxidizing. This is consistent with the fact that these serpentines are richer in $\mathrm{Fe}(\mathrm{III})$.

In Fig. 7, quartz solubility is shown. Si concentrations measured in groundwater fall close to the solubility of the different serpentines (except that of YAM-179 calculated at $0.4 \mathrm{~V}$ ) and quartz, indicating that groundwater could be near equilibrium with these minerals, as suggested by the saturation indices calculated for groundwater samples (Fig. 6b). This is coherent with the observation of quartz (mixed with goethite) replacing olivine grains in the saprolite samples, surrounded by serpentine (Fig. $3 \mathrm{~d}$ ).

In addition, Fig. 7 displays goethite solubility, calculated at $\mathrm{Eh}=-0.4,-0.3$, and $0.4 \mathrm{~V}$, given the high dependence of goethite solubility on this parameter. As can be seen, Fe concentrations measured in groundwater are similar to the solubility of serpentine at the $\mathrm{pH}$ range measured in the field, but also to the solubility of goethite at reducing Eh $(-0.4$ and $-0.3 \mathrm{~V})$. Porewater samples are far from solubility of goethite at $0.4 \mathrm{~V}$. Therefore, it can be stated that the saprolite horizon of the Falcondo Ni-laterite, where goethite and serpentine have been observed close to equilibrium, must be under slightly reducing conditions rather than under slightly oxidizing conditions. $\mathrm{Mg}$ and $\mathrm{Ni}$ aqueous concentration are also close to the solubility of serpentine calculated at $-0.3 \mathrm{~V}$.

Figure 8 shows the predominance diagram $\mathrm{pH}-\mathrm{Eh}(\mathrm{V})\left(25^{\circ} \mathrm{C}, 1 \mathrm{~atm}\right)$ of the $\mathrm{Fe}$ system for water compositions of the Falcondo Ni-laterite deposit. The stability field for LC-107 sample, representing the most common serpentine composition analyzed $\left.\left(\mathrm{Mg}_{2.625} \mathrm{Fe}^{3+}{ }_{0.166} \mathrm{Ni}_{0.126}\right) \mathrm{Si}_{2} \mathrm{O}_{5}(\mathrm{OH})_{4}\right)$, indicates that this phase is stable at $\mathrm{pH}$ higher than 8.0 and Eh lower than $-0.2 \mathrm{~V}$. This stability field slightly decreases for serpentines with compositions similar to LO-17, that is with more $\mathrm{Mg}$ and less $\mathrm{Fe}(\mathrm{III})$ $\left(\left(\mathrm{Mg}_{2.776} \mathrm{Fe}^{3+}{ }_{0.056} \mathrm{Ni}_{0.140}\right) \mathrm{Si}_{2} \mathrm{O}_{5}(\mathrm{OH})_{4}\right)$ (Fig. 8). However, an increase of $\mathrm{Fe}(\mathrm{III})$ in the octahedral sites such as in sample YAM-179 $\left(\left(\mathrm{Mg}_{2.321} \mathrm{Fe}^{3+}{ }_{0.382} \mathrm{Ni}_{0.106}\right) \mathrm{Si}_{2} \mathrm{O}_{5}(\mathrm{OH})_{4}\right)$ significantly enhances the stability of 
serpentine towards higher, even oxidizing, Eh values (Fig. 8).

Fig. 8

$\mathrm{Eh}(\mathrm{V})-\mathrm{pH}$ predominance diagram of $\mathrm{Fe}\left(2.5 \times 10^{-6} \mathrm{M}\right)$. $\left[\mathrm{SO}_{4}{ }^{2-}\right]_{\text {tot }}=2.0 \times 10^{-4} \mathrm{M} ;[\mathrm{Cl}-]_{\text {tot }}=2.0 \times 10^{-4} \mathrm{M} ;\left[\mathrm{CO}_{3}{ }^{2-}\right]_{\text {tot }}=1.7 \times 10^{-3} \mathrm{M}$; $\left[\mathrm{Ca}^{2+}\right]_{\mathrm{tot}}=3.1 \times 10^{-5} \mathrm{M} ;\left[\mathrm{Mg}^{2+}\right]_{\mathrm{tot}}=1.0 \times 10^{-3} \mathrm{M} ;\left[\mathrm{Si}^{4++}\right]_{\mathrm{tot}}=3.6 \times 10^{-4} \mathrm{M}$; $[\mathrm{Ni}]_{\text {tot }}=5.5 \times 10^{-7} \mathrm{M}$, for samples LC-107 (a), LO-17 (b), and YAM-179 (c). Eh and $\mathrm{pH}$ values of porewater samples were calculated with PHREEQC v.3 to be in equilibrium with serpentine and goethite 

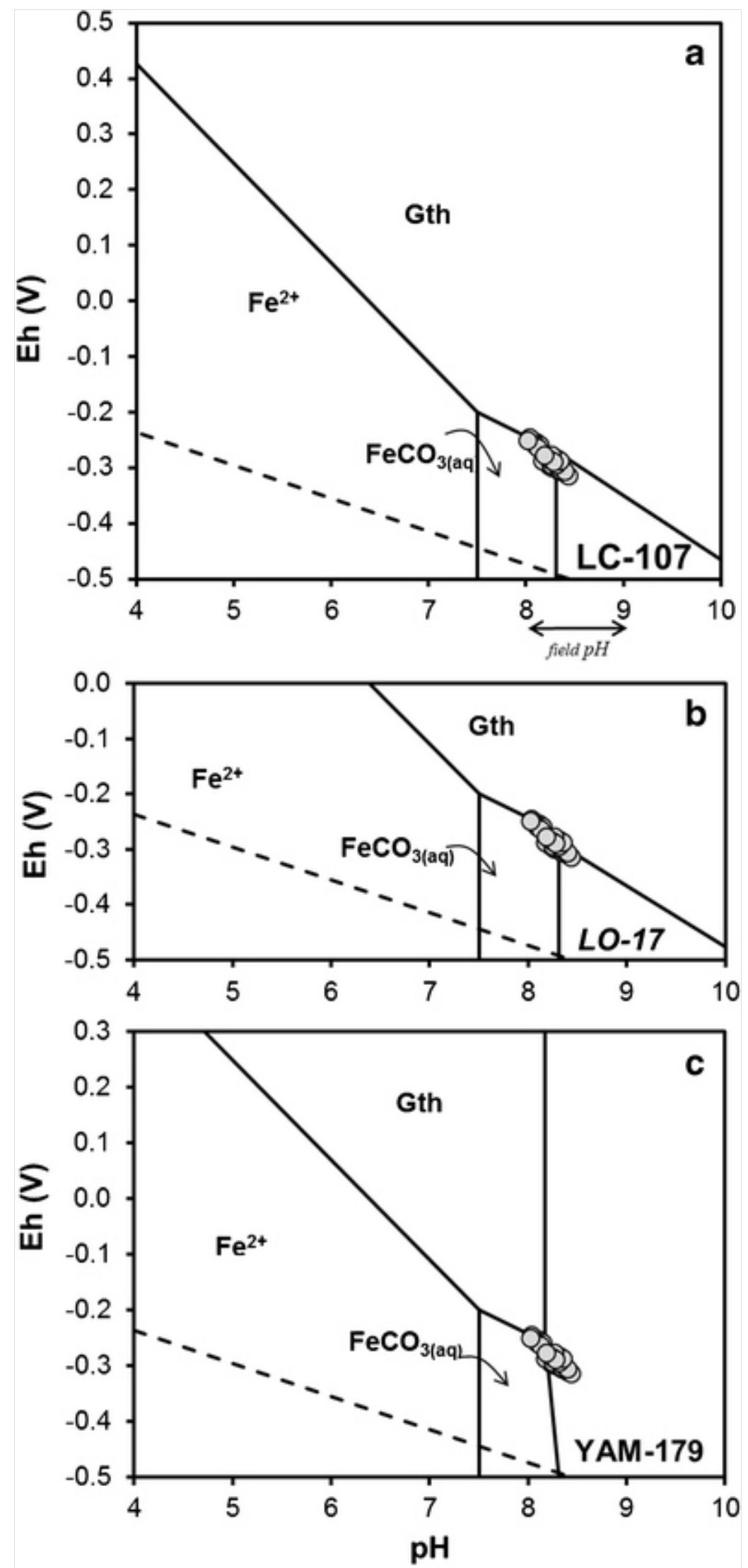

Porewater in equilibrium with serpentine and goethite

The Eh value of each porewater sample has been calculated assuming that porewater is simultaneously in equilibrium with goethite and serpentine II. In these calculations, performed for LC-107, LO-17, and YAM-179 samples, $\mathrm{pH}$ 
has also been recalculated to allow water to be in equilibrium with the minerals. Results (Fig. 8) show that $\mathrm{pH}$ should be between 8.0 and 8.5 and Eh between -0.24 and $-0.31 \mathrm{~V}$, in agreement with the previous calculations.

According to the results presented here, which show agreement between serpentine mineralogical characteristics, saprolite horizon porewater analyses and thermodynamic calculations at $25{ }^{\circ} \mathrm{C}$, the formation of a $\mathrm{Fe}$ (III)Ni-bearing serpentine in the saprolite horizon of a Ni-laterite deposit may take place under atmospheric pressure and temperature, suggesting that these processes can be occurring near the surface.

\section{Conclusions}

The detailed mineralogical study of the saprolite horizon of Ni-laterites from the Caribbean region reveals that it is mainly composed of lizardite surrounding silicified cores of Fe-oxyhydroxides (goethite). Two serpentines are distinguished by their composition: (i) serpentine I, with low $\mathrm{Ni}$ and $\mathrm{Fe}$ contents, of hydrothermal origin and (ii) serpentine II, enriched in $\mathrm{Ni}$ and $\mathrm{Fe}$, and formed during lateritization by exchange of $\mathrm{Mg}$ by $\mathrm{Ni}$ and $\mathrm{Fe}$. $\mathrm{A}$ representative number of EPMA analyses show that the $\mathrm{Fe}$ and $\mathrm{Ni}$ contents in serpentine II range from 2.23 to 15.59 wt. $\% \mathrm{Fe}_{2} \mathrm{O}_{3}$ and $1.30-7.00$ wt. $\% \mathrm{NiO}$, respectively. Ni contents considerably differ from those in serpentine I $(0.1-0.62 \mathrm{wt} . \% \mathrm{NiO})$ and reproduce those of the primary minerals of the ultramafic protolith. Ni and Fe in serpentine II display a positive correlation, whereas the correlation of these two elements with $\mathrm{Mg}$ is negative. This indicates the substitution of $\mathrm{Mg}$ by $\mathrm{Fe}$ (III) and $\mathrm{Ni}$ in the octahedral position. This correlation is not found in serpentine I, where Ni contents are low.

Thermodynamic calculations were carried out assuming that serpentine II is the combination of three end members: lizardite, népouite, and $\mathrm{Fe}(\mathrm{III})-$ lizardite. Following Blanc et al. (2015) a $\log K^{0}$ value of $19 \pm 4$ for népouite (r.7) and of $-1 \pm 4$ for Fe(III)-lizardite (r.8) have been calculated. These values, together with $\log K^{0}$ of lizardite have been used to calculate the solubility constants corresponding to the different serpentine II compositions. Despite compositional variations of serpentine II, $\log K^{0}$ only ranges from $31.4 \pm 0.9$ to $25 \pm 1$. No significant differences are observed for $\log K^{0}$ from Caribbean serpentines or even with serpentines II from the literature.

The thermodynamic calculations performed with three different serpentine II compositions covering the range of $\log K^{0}$ calculated indicate that serpentine II 
solubility is highly dependent on $\mathrm{pH}$, especially in the range 7.5-8.5, while the effect of Eh is negligible except for those cases with higher Fe(III). In those cases, the stability field of serpentine II increases towards oxidizing conditions.

Solubility calculations provide $\mathrm{Fe}, \mathrm{Si}, \mathrm{Ni}$, and $\mathrm{Mg}$ concentrations similar to those measured in groundwater samples from the saprolite horizon of the Falcondo Ni-laterite from the literature. Eh and $\mathrm{pH}$ values of the porewater samples, calculated assuming that porewater is simultaneously in equilibrium with goethite and serpentine II, show that $\mathrm{pH}$ should be between 8.0 and 8.5 and Eh between -0.24 and $-0.31 \mathrm{~V}$.

Geochemical calculations indicate an agreement between serpentine mineralogical characterization, saprolite horizon porewater analyses, and thermodynamic calculations at $25^{\circ} \mathrm{C}$, suggesting both that the formation of a $\mathrm{Fe}$ (III)-Ni-bearing serpentine in the saprolite horizon of a Ni-laterite deposit may take place under atmospheric pressure and temperature and that these processes are currently occurring near the surface.

\section{Acknowledgments}

This research has been financially supported by FEDER Funds, the Spanish projects CGL2009-10924 and CGL2012-36263, and Catalan project 2014-SGR-1661 and a PhD grant to Cristina Villanova-de-Benavent sponsored by the Ministerio de Educación (Spain). The help and hospitality extended by the staff at Falcondo Xstrata mine are also gratefully acknowledged. The authors also thank Dr. Thomas Aiglsperger for the comments on the paper prior to submission and Prof. J.P. Golightly, Editorin-Chief Georges Beaudoin, Associate Editor Beate Orberger and two anonymous reviewers for their accurate revisions and constructive suggestions that highly improved the quality of the manuscript.

Compliance with ethical standards

Conflict of interest The authors declare that they have not conflict of interest.

\section{References \\ AQ12}

Aiglsperger T, Proenza JA, Lewis JF, Labrador M, Svojtka M, Rojas-Purón 
A, Longo F, Ďurišová J (2016) Critical metals (REE, Sc, PGE) in Ni laterites from Cuba and the Dominican Republic. Ore Geol Rev 73:127-147

Blanc P, Lassin A, Piantone P, Azaroual M, Jacquemet N, Fabbri A, Gaucher EC (2012) Thermoddem: a geochemical database focused on low temperature water/rock interactions and waste materials. Appl Geochem 27:2107-2116

Blanc P, Vieillard P, Gailhanou H, Gaboreau S, Gaucher E, Fialips CI, Madé B, Giffaut E (2015) A generalized model for predicting the thermodynamic properties of clay minerals. Am J Sci 315:734-780

Boschetti T, Toscani L (2008) Springs and streams of the Taro-Ceno valleys (northern Apennine, Italy): reaction path modeling of waters interacting with serpentinized ultramafic rocks. Chem Geol 257:76-91

Brand NW, Butt CRM, Elias M (1998) Nickel laterites: classification and features. AGSO J Australian Geol Geoph 17:81-88

Cathelineau M, Quesnel B, Gautier P, Boulvais P, Couteau C, Drouillet M (2015) Nickel dispersion and enrichment at the bottom of the regolith: formation of pimelite target-like ores in rock block joints (Koniambo Ni deposit, New Caledonia. Mineral Deposita:1-12. doi:

10.1007/s00126-015-0607-y

Chen, TT, Dutrizac, JE, Krause, E, Osborne, R (2004) Mineralogical characterization of nickel laterites from New Caledonia and Indonesia. Int Laterite Nickel Symposium, pp. 79-99)

Chermak JA, Rimstidt JD (1989) Estimating the thermodynamic properties $\left(\Delta \mathrm{G}_{\mathrm{f}}^{0}\right.$ and $\left.\Delta \mathrm{H}_{\mathrm{f}}^{0}\right)$ of silicate minerals at $298 \mathrm{~K}$ from the sum of polyhedral contributions. Am Mineral 74:1023-1031

Dalvi, AD, Gordon Bacon, W, Osborne, RC (2004) The past and the future of nickel laterites.

Evans BW (2004) The serpentinite multisystem revisited:chrysotile is metastable. Int Geol Rev 46:479-506. doi: 10.2747/0020-6814.46.6.479 
Evans BW, Kuehner SM, Chopelas A (2009) Magnetite-free, yellow lizardite serpentinization of olivine websterite, Canyon Mountain complex, NE Oregon. Am Mineral 94:1731-1734

Freyssinet, Ph, Butt, CRM, Morris, RC (2005) Ore-forming processes related to lateritic weathering: Econ Geol 100th Anniv Vol:681-722

Galí S, Soler JM, Proenza JA, Lewis JF, Cama J, Tauler E (2012) Ni-enrichment and stability of Al-free garnierite solid-solutions: a thermodynamic approach. Clay Clay Miner 60:121-135

Gallardo T, Tauler E, Proenza JA, Lewis JF, Galí S, Labrador M, Longo F, Bloise G (2010) Geology, mineralogy and geochemistry of the Loma Ortega Ni laterite deposit, Dominican Republic. Macla 13:89-90

Gamelin FX, Baquet G, Berthoin S, Thevenet D, Nourry C, Nottin S, Bosquet L (2009) Effect of high intensity intermittent training on heart rate variability in prepubescent children. Eur J Appl Physiol 105:731-738

Giffaut E, Grivé M, Blanc P, Vieillard P, Colàs E, Gailhanou H, Gaboreau S, Marty N, Madé B, Duro L (2014) Andra thermodynamic database for performance assessment: ThermoChimie. Appl Geochem 49:225-236

Gleeson SA, Butt CR, Elias M (2003) Nickel laterites: a review: SEG. Newsletter 54:11-18

Golightly, JP (1981) Nickeliferous laterite deposits. Econ Geol 75th Anniv Vol: 710-735.

Golightly JP (2010) Progress in understading the evolution of nickel laterites. Econ Geol Spec Pub 15:451-485

Golightly JP, Arancibia ON (1979) The chemical composition and infrared spectrum of nickel- and iron-substituted serpentine form a nickeliferous laterite profile, Soroako, Indonesia. Can Mineral 17:719-728

Haldemann E, Buchan R, Blowes J, Chandler T (1979) Geology of lateritic nickel deposits, Dominican Republic. International Laterite Symposium 4:57-84 
Klein F, Bach W, Jons N, McCollom T, Moskowitz B, Berquo T (2009) Iron partitioning and hydrogen generation during serpentinization of abyssal peridotites from 15 degrees $\mathrm{N}$ on the mid-Atlantic ridge. Geochim Cosmochim Acta 73:6868-6893

Kuck, PH (2013) Nickel. USGS Mineral Commodity Summaries 108-109

Landauro Sotelo, EL (2008) Evaluación del riesgo ambiental por lixiviado de metales en residuos mineros y suelos empleando cuatro métodos de extracción secuencial. Master Thesis, Universitat de Girona and Universidad Politécnica de Madrid

Lewis J, Jimenez J (1991) Duarte complex in the La Vega-Jarabacoa-Janico Area, Central Hispaniola: geological and geochemical features of the sea floor during the early stages of the arc evolution. In Geologic and Tectonic development of the North America-Caribbean Plate Boundary in Hispaniola (Mann, P., Draper, G., Lewis, J.F.). Geological Society of America, Special Paper 262, 115-142.

Lewis JF, Draper G, Proenza JA, Espaillat J, Jimenez J (2006) Ophioliterelated ultramafic rocks (serpentinites) in the Caribbean region: a review of their occurrence, composition origin, emplacement and Ni-laterite soils formation. Geol Acta 4:237-263

Lithgow, E (1993) Nickel laterites of central Dominican Republic Part I. Mineralogy and ore dressing. In: Reddy, R.G., Weizenbach, R.N. (Eds.), The Paul E. Queneau Int. Symposium, Extractive Metallurgy of Copper, Nickel and cobalt, Volume I: Fundamental aspects. The Minerals, Metals and Materials Society, Portland, 403-42.

Luce, RW (1971) Identification of serpentine varieties by infra-red absorption: USGS Prof. Paper 750B, 199-201

Marchesi, C, Garrido, C, Proenza, J, Konc, Z, Hidas, K, Lewis, J (2012). Mineral and whole rock compositions of peridotites from Loma Caribe (Dominican Republic): insights into the evolution of the oceanic mantle in the Caribbean region. Geophysical Research, Abstract 14 of EGU general assembly, 2012. Vienna, Austria, 22-27

Mondesir H, Decarreau A (1987) Synthesis between $25^{\circ} \mathrm{C}$ and $200{ }^{\circ} \mathrm{C}$ of 
$\mathrm{Ni}-\mathrm{Mg}$ lizardites - experimental partition of $\mathrm{Ni}$ and $\mathrm{Mg}$ between lizardites and water. B Mineral 110:409-426

Mudd GM (2010) Global trends and environmental issues in nickel mining: sulfides versus laterites. Ore Geol Rev 38:9-26

Mudd GM, Jowitt SM (2014) A detailed assessment of global nickel resource trends and endowments. Econ Geol 109:1813-1841

Nelson CE, Proenza JA, Lewis JF, López-Kramer J (2011) The metallogenic evolution of the greater Antilles. Geol Acta 9:229-264

Normando, M.L. (2006). Caracterización Mineralógica del Perfil Saprolítico del Depósito de Lateritas Niquelíferas Yamanigüey. PhD Thesis, Universidad de Barcelona.

Nriagu JO (1975) Thermochemical approximation for clay minerals. Am Mineral 60:834-839

Orberger B, Friedrich G, Woermann (1990) The distribution of halogens and carbon in PGE-bearing ultramafics of the Acoje ophiolite block, Zambales, Philippines. J Geochem Expl 37:147-169

Parkhurst, DL, Appelo, CAJ (2012) Description of input and examples for PHREEQC version 3-a computer program for speciation, batch-reaction, one-dimensional transport, and inverse geochemical calculations. USGS Techniques and Methods, book 6, chap. A43, 497 p., available only at http://pubs.usgs.gov/tm/06 A43/

PDAC Int. Convention, Toronto, Canada, p. 27.Evans BW (2008) Control of the products of serpentinization by the $\mathrm{Fe}^{2+} \mathrm{Mg}_{-1}$ exchange potential of olivine and orthopyroxene. J Petrol 49:1873-1887

Pelletier, B (1996) Serpentines in nickel silicate ore from New Caledonia. Australasian Institute of Mining and Metallurgy Publication Series Nickel Conference, Kalgoorlie (Western Australia) 6/96:197-205.

Proenza JA, Melgarejo JC, Gervilla F (2003) Comments on the paper "Ochreous laterite: a nickel ore from Punta Gorda, Cuba" by Oliveira et al. J S Am Earth Sci 16:199-202 
Proenza JA, Tauler E, Melgarejo JC, Galí S, Labrador M, Marrero N, Pérez-Melo N, Rojas-Purón AL, Blanco-Moreno JA (2007) Mineralogy of oxide and hydrous silicate Ni-laterite profiles in Moa Bay area, northeast Cuba. In: Andrew et al. (eds.), Digging Deeper, Irish Association for Economic Geology, Dublin, Ireland. 2: 1389-1392

Puigdomènech, I (2010) MEDUSA (Make Equilibrium Diagrams Using Sophisticated Algorithms) Windows interface to the MS-DOS versions of INPUT, SED and PREDOM (FORTRAN programs drawing chemical equilibrium diagrams) version 6 Dec 2010. Royal Institute of Technology, Stockholm, Sweden

Robie, RA, Hemingway, BS (1995) Thermodynamic properties of minerals and Related Substances at $298.15 \mathrm{~K}$ and 1 bar $\left(10^{5}\right)$ Pascals) pressure and higher temperatures: U.S. Geological Survey Bulletin, v. 2131, 461 p.

Roqué-Rosell, J, Villanova-de-Benavent, C, Proenza, JA (2016) The accumulation of $\mathrm{Ni}$ in garnierites and serpentines from Falcondo Ni-laterite deposit (Dominican Republic) elucidated by means of $\mu$ XAS. Geochim Cosmochim Acta (in press)

Sleep NH, Meibom A, Fridriksson T, Coleman RG, Bird DK (2004) H2-rich fluids from serpentinization: geochemical and biotic implications. PNAS 101(35):12818-12823

Streit E, Kelemen P, Eiler J (2012) Coexisting serpentine and quartz from carbonate-bearing serpentinized peridotite in the Smail ophiolite, Oman. Contrib Mineral Petr 164:821-837

Tauler E, Buen H, Proenza JA, Galí S, Melgarejo JC, Labrador M, Marrero N (2007) Tres generaciones de serpentina en el perfil laterítico del NE de Cuba. Macla 7:110

Tauler E, Proenza J, Galí S, Lewis J, Labrador M, García-Romero E (2009) Ni-sepiolite-falcondoite in garnierite mineralisation from the Falcondo Ni-laterite deposit, Dominican Republic. Clay Miner 44:435-454

Trescases, JJ (1973) L'évolution géochimique supergène des roches ultrabasiques en zone tropicale et la formation des gisements nickélifères de Nouvelle-Calédonie. PhD thesis, Université Louis Pasteur, Strasbourg. 
Trescases JJ (1979) Remplacement progressif des silicates par les hydroxides de fer et de nickel dans les profils d'altération tropicale des roches ultrabasiques. Accumulation résiduelle et épigenie. Sci Géol Bull 32:181-188

Vieillard P (1994a) Prediction of enthalpy of formation based on refined crystal structures of multisite compounds: part 1. Theories and examples. Geochim Cosmochim Acta 58:4049-4063. doi:

10.1016/0016-7037(94)90266-6

Vieillard P (1994b) Prediction of enthalpy of formation based on refined crystal structures of multisite compounds: part 2. Application to minerals belonging to the system $\mathrm{Li}_{2} \mathrm{O}-\mathrm{Na}_{2} \mathrm{O}-\mathrm{K}_{2} \mathrm{O}-\mathrm{BeO}-\mathrm{MgO}-\mathrm{CaO}-\mathrm{MnO}-\mathrm{FeO}-$ $\mathrm{Fe}_{2} \mathrm{O}_{3}-\mathrm{Al}_{2} \mathrm{O}_{3}-\mathrm{SiO}_{2}-\mathrm{H}_{2} \mathrm{O}$. Results and discussion. Geochim Cosmochim Acta 58:4065-4107. doi: 10.1016/0016-7037(94)90267-4

Vieillard P (2000) A new method for the prediction of Gibbs free energies of formation of hydrated clay minerals based on the electronegativity scale. Clay Clay Miner 48:459-473

Vieillard P (2002) A new method for the prediction of Gibbs free energies of formation of phyllosilicates (10 A and 14 A) based on the electronegativity scale. Clay Clay Miner 50:352-363

Villanova-de-Benavent C, Proenza JA, Galí S, García-Casco A, Tauler E, Lewis JF, Longo F (2014) Garnierites and garnierites: textures, mineralogy and geochemistry of garnierites in the Falcondo Ni-laterite deposit, Dominican Republic. Ore Geol Rev 58:91-109

Wells MA, Ramanaidou ER, Verrall M, Tessarolo C (2009) Mineralogy and crystal chemistry of garnierites in the Goro lateritic nickel deposit, New Caledonia. Eur J Mineral 21:467-483

Whitney DL, Evans BW (2010) Abbreviations for names of rock-forming minerals. Am Mineral 95:185-187

Wicks FJ, Plant AG (1979) Electron microprobe and X-ray microbeam studies of serpentine textures. Can Mineral 17:785-830

Wilson J, Savage D, Cuadros J, Shibata M, Ragnasdottir KV (2006) The 
effect of iron on montmorillonite stability. (I) background and thermodynamic considerations. Geochim Cosmochim Acta 70:306-322 